\title{
Mitochondrial RNA Expression and Single Nucleotide Variants in Association with Clinical Parameters in Primary Breast Cancers
}

\author{
Marjolein J. A. Weerts *, Marcel Smid, John A. Foekens, Stefan Sleijfer and John W. M. Martens \\ Department of Medical Oncology and Cancer Genomics Netherlands, Erasmus MC Cancer Institute, \\ Erasmus University Medical Center, 3015 CE Rotterdam, The Netherlands; m.smid@erasmusmc.nl (M.S.); \\ j.foekens@erasmusmc.nl (J.A.F.); s.sleijfer@erasmusmc.nl (S.S.); j.martens@erasmusmc.nl (J.W.M.M.) \\ * Correspondence: m.weerts@erasmusmc.nl; Tel.: +31-107-044-375; Fax: +31-107-044-377
}

Received: 10 November 2018; Accepted: 7 December 2018; Published: 9 December 2018

\begin{abstract}
The human mitochondrial DNA (mtDNA) encodes 37 genes, including thirteen proteins essential for the respiratory chain, and RNAs functioning in the mitochondrial translation apparatus. The total number of mtDNA molecules per cell (mtDNA content) is variable between tissue types and also between tumors and their normal counterparts. For breast cancer, tumors tend to be depleted in their mtDNA content compared to adjacent normal mammary tissue. Various studies have shown that primary breast tumors harbor somatic mtDNA variants. A decrease in mtDNA content or the presence of somatic variants could indicate a reduced mitochondrial function within breast cancer. In this explorative study we aimed to further understand genomic changes and expression of the mitochondrial genome within breast cancer, by analyzing RNA sequencing data of primary breast tumor specimens of 344 cases. We demonstrate that somatic variants detected at the mtRNA level are representative for somatic variants in the mtDNA. Also, the number of somatic variants within the mitochondrial transcriptome is not associated with mutational processes impacting the nuclear genome, but is positively associated with age at diagnosis. Finally, we observe that mitochondrial expression is related to ER status. We conclude that there is a large heterogeneity in somatic mutations of the mitochondrial genome within primary breast tumors, and differences in mitochondrial expression among breast cancer subtypes. The exact impact on metabolic differences and clinical relevance deserves further study.
\end{abstract}

Keywords: primary breast cancer; mitochondrial RNA variants; mitochondrial expression; clinicopathological markers

\section{Introduction}

Mitochondria are small organelles involved in multiple cellular processes. They are most renowned for their role in energy production, since they contain their own circular genomic entity encoding proteins essential for the respiratory chain and thereby for generating cellular ATP via oxidative phosphorylation. The human mitochondrial DNA (mtDNA) is gene-dense consisting of 16569 base pairs encoding 37 genes: thirteen proteins, and two rRNAs and twenty-two tRNAs functioning in the mitochondrial translation apparatus. Polycistronic transcription of mtDNA is initiated at the non-coding D-loop region, and the resultant precursor transcripts are processed by excision of the tRNA genes ("tRNA punctuation model" [1]) generating individual mitochondrial tRNA, rRNA and mRNA transcripts. The total number of mtDNA molecules per cell (mtDNA content) is variable between tissue types, and interestingly also between tumors and their normal counterparts [2]. For breast cancer specifically, tumors tend to have reduced mtDNA content compared 
to adjacent normal mammary tissue [2-10], and mtDNA content in breast tumors positively correlates with the expression of mtDNA-encoded genes [11]. Decreased content and expression of mtDNA could indicate a reduced mitochondrial oxidative phosphorylation function within breast cancer, in line with the Warburg hypothesis [12] limiting energy production largely to glycolysis. Recently, we have shown mtDNA content to be associated with breast cancer patient outcome [13,14], underlining the clinical relevance of mitochondria in breast cancer.

Apart from mtDNA content, the significance of somatic mtDNA variants within (breast) cancer is still subject to debate, where the whole spectrum of neutral accumulation, positive selection (advantage) and negative selection (disadvantage) have been postulated. Various studies have shown that primary breast tumors harbor somatic variants in their mtDNA $[8,15,16]$, with approximately $70 \%$ of the specimens containing at least one single nucleotide variant (SNV, range 1-7) and $10 \%$ containing at least one small insertion/deletion (INDEL, range 0-3). However, these variants do not appear at particular 'hot-spot' positions on the mitochondrial genome, raising doubts about their clinical relevance.

To better understand nucleotide changes in and expression of the mitochondrial genome within primary breast tumors, we investigated here transcriptomic sequencing data within the International Cancer Genome Consortium (ICGC) [17] and explored how these findings correlate with clinical parameters, providing more insight into the mitochondrial genome as potential biomarker and its clinical relevance in breast cancer.

\section{Results}

We evaluated RNA sequencing data of 344 primary breast tumor specimens. After mapping of sequencing reads against the human reference genome, median 15\% (Interquartile range (IQR) 10-23\%) of the uniquely mapped reads were assigned to the mitochondrial contig, resulting in median $9889 \times$ read depth (IQR 5333) of mtDNA.

\subsection{Somatic Variants in $m t R N A$}

Variant calling resulted in a total of 9063 single nucleotide variants (SNVs) on 1600 positions and 84 small insertions or deletions (INDELs) on 38 positions of the mitochondrial genome within the 344 cases (Figure 1). Since INDELs were only a minority, our focus was on the SNVs only. We defined SNVs as somatically acquired tumor variants when not associated with the individual's haplotype ( $n=7235$ excluded, $80 \%$ ) or with heteroplasmic allele frequency of $\leq 95 \%$ ( $n=917$ excluded, $10 \%$ ). Also, we defined the variants at position 2617 (r.2617a $>\mathrm{u}$ and $\mathrm{r} .2617 \mathrm{a}>\mathrm{g}$, present in respectively $n=340$ and $n=101$ cases) as not tumor-specific because (1) they have been described previously as RNA-DNA differences in blood cells of non-cancer patients $[18,19]$ and (2) we confirmed their presence in a transcriptomic dataset of normal specimens of various tissue types including breast tissue [20] (Supplementary Materials Table S1). After these exclusions, a total of 470 somatic variants on 429 positions were identified.

Our dataset has overlapping cases $(n=165)$ with the dataset published by Ju et al. [15] concerning somatic mitochondrial variants in tumor and matched normal specimens at the DNA level. This allowed us to directly compare called variants between the two datasets (see also Appendix A) to evaluate presence, classification and allele frequency of variants. Since variants at position 2617 are known RNA-DNA differences (see above) and indeed not called in the DNA dataset, these were not included in this comparison. A total of respectively 3997 and 4009 SNVs were called at the RNA and DNA level within the primary tumor specimens of the 165 cases. The majority of the variants were called at both the RNA and DNA level $(n=3889$, respectively $97.3 \%$ and $97.0 \%)$, whereas a small fraction was only called at either the RNA or the DNA level (respectively $n=108(2.7 \%)$ and $n=120(3.0 \%)$ variants) (Figure 2). Of the variants detected at both the RNA and DNA level, only a few $(n=10,0.3 \%)$ had a discrepancy in classification as either 'somatic' or 'germline' (Figure 2). Also, good consistency was observed in allele frequency at the RNA and DNA level (linear fit coefficient of 0.92 for all variants and 0.96 for somatic tumor variants). From this we concluded that presence, 
classification and allele frequency of variants was consistent between the RNA and the DNA level (as elaborated on in the Appendix A).

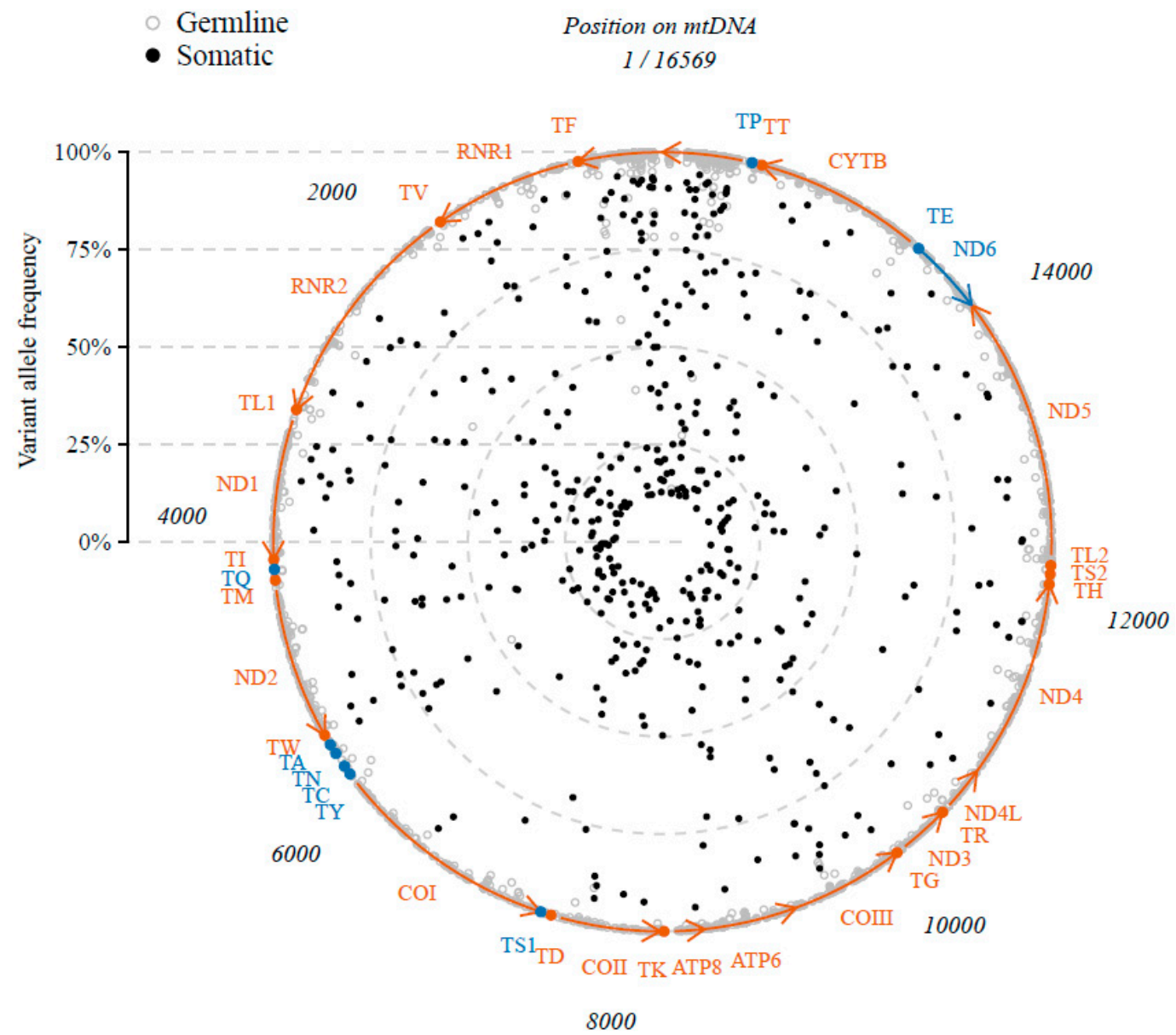

Figure 1. Variants in the mitochondrial RNA of 344 primary breast tumor cases. Position on the mitochondrial genome (circle) and their variant allele frequency (increasing \% from inner-to-outer) of all variants identified in the 344 cases. Somatic or germline origin in respectively closed black or open grey circles. Genes and their direction of transcription (arrows) in red (+strand) or blue (-strand). Note that variants on position 2617 (known RNA-DNA differences) are not shown.

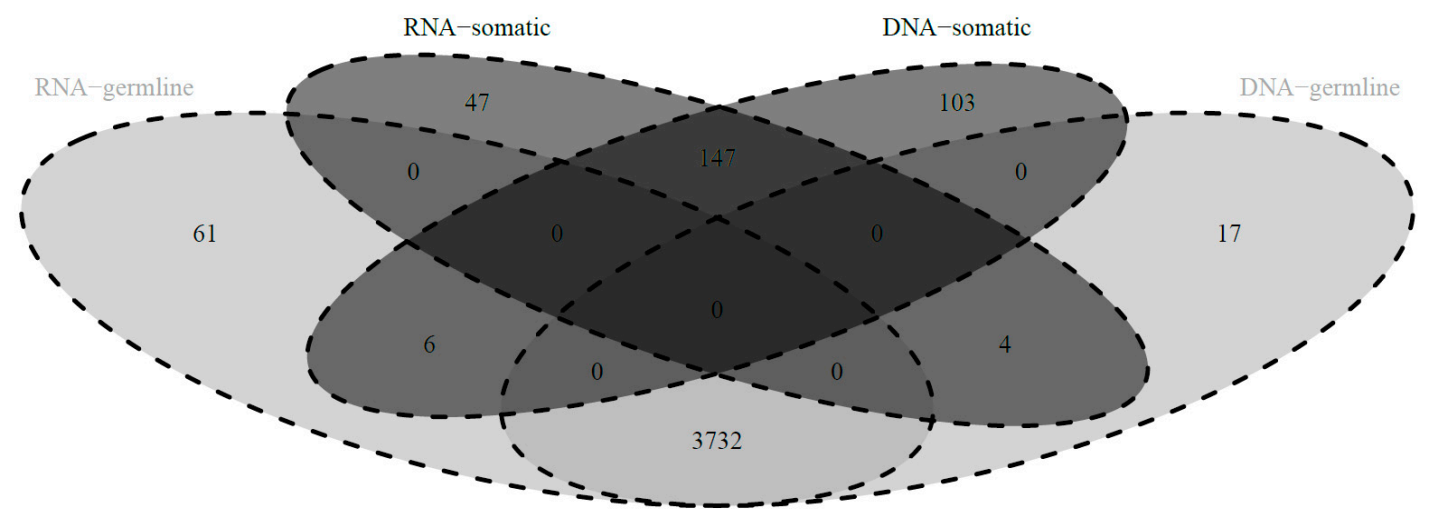

Figure 2. Classification of variants detected in the mitochondrial RNA and in the mitochondrial DNA of 165 primary breast tumor cases. Venn-diagram depicting classification of variants as either somatic (black) or germline (grey) at the RNA level and the DNA level. 
We then continued to further decipher the somatic mtRNA variants in our dataset $(n=470$ in $n=344$ cases). The variant allele frequency of the somatic variants was distributed with a peak at the lower and at the upper end of allele frequencies (Supplementary Materials Figure S1). There was no correlation between the variant allele frequency and the percentage of invasive tumor cells in the evaluated specimen (Spearman correlation coefficient rho $=0.03, p=0.5$ ). The detected somatic variants were distributed along the entire mitochondrial genome (Figure 1$)$, with $40(8.5 \%)$ variants located in the tRNA genes, 69 (14.7\%) in rRNA genes, 85 (18.1\%) in the D-loop, $1(0.2 \%)$ in the non-coding regions, and $275(58.5 \%)$ in the mRNA genes of which $212(77.1 \%)$ had a nonsynonymous effect on the coding amino acid (Figure 3). However, relative to their genomic size (9.0\% tRNA genes, $15.1 \%$ rRNA genes, $6.8 \%$ D-loop, $0.4 \%$ non-coding and $68.7 \%$ mRNA genes) more variants were present in the D-loop and fewer in the mRNA genes (Fisher exact $p<0.001$ ). Also in comparison to the germline variants (variants that were associated with the haplogroup of that individual or with an allele frequency $>95 \%, n=8152$ ) there was a difference in genomic distribution (Fisher's exact $p<0.001$ ) with fewer somatic variants in the D-loop but more in the tRNA and mRNA genes, and an enrichment for somatic nonsynonymous mRNA variants (Figure 3). The positions of somatic variants were much more conserved among species compared to the germline variants (Mann-Whitney test $p<0.001$ ), as measured by the fraction of species that harbor the reference sequence at that position (Conservation Index of respectively median (IQR) $0.93(0.36)$ and $0.76(0.69))$. A total of $69(15 \%)$ somatic variants were recurrent and positioned on 28 mitochondrial positions. The majority of the somatic variants (95\%) represented the typical replication-coupled mtDNA substitution pattern with predominantly $\mathrm{C}>\mathrm{T}$ and $\mathrm{T}>\mathrm{C}$ transitions as described previously $[15,16,21]$ in a nucleotide context similar to the germline variants (Figure 4). However, compared to the detected germline variants the ratio between $\mathrm{C}>\mathrm{T}$ and $\mathrm{T}>\mathrm{C}$ variants is shifted (Fisher exact $p<0.001$ ) with an increased number of $C>T$ transitions among the somatic variants (Figure 4).

In the entire cohort, there are $112(33 \%)$ cases with 0 somatic variants, $97(28 \%)$ with 1 somatic variant, and 135 (39\%) with more than 1 somatic variant (range 2 to 7$)$. Of the cases with more than 1 somatic variant, $82(61 \%)$ had a difference $>20 \%$ allele frequency between variants, indicative for (sub-)clonality.

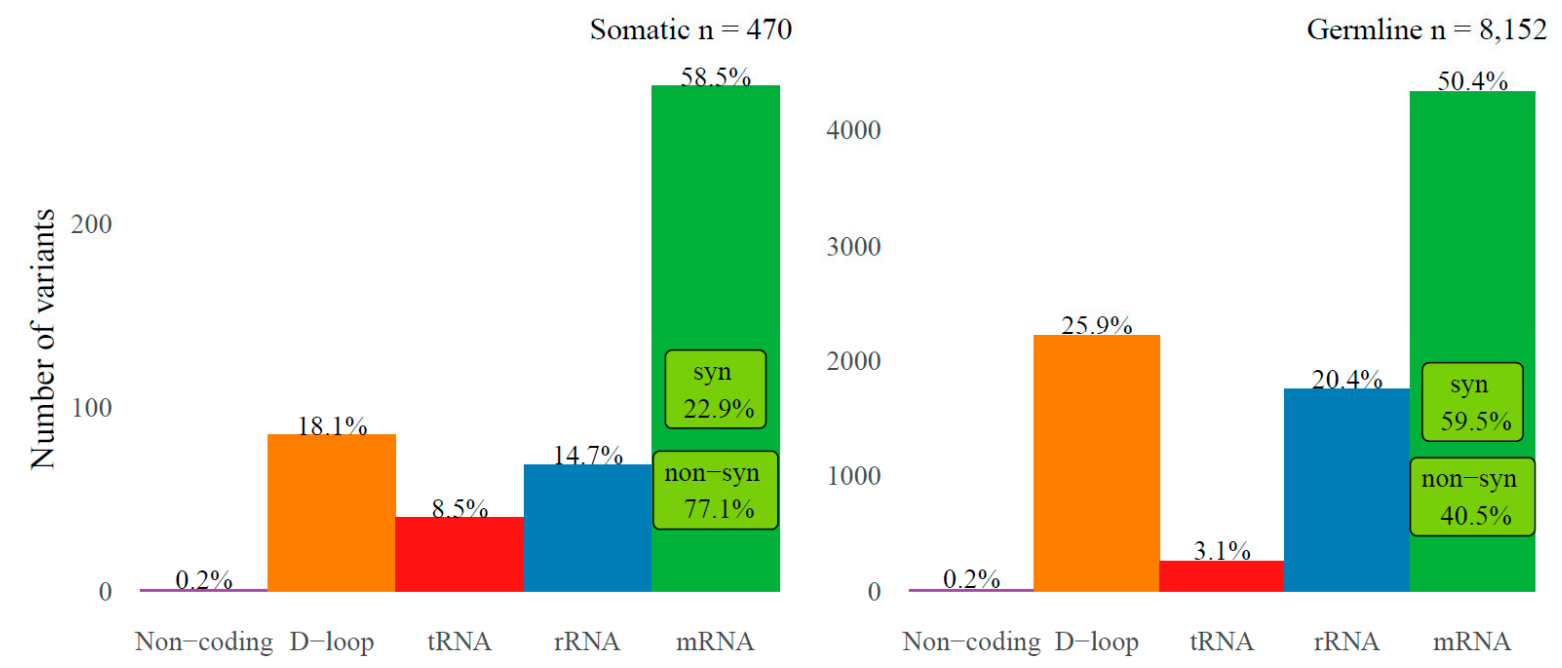

Figure 3. Genomic distribution of mitochondrial RNA variants of 344 primary breast tumor cases. Genomic distribution is depicted for somatic (left) or germline (right) variants in either non-coding (purple), the D-loop (orange), tRNA (red), rRNA (blue) or mRNA (green) regions of the mitochondrial genome. The percentage of total is indicated at the top of the bars. The percentage of substitutions in the mRNA regions with either a synonymous or nonsynonymous effect is indicated within the mRNA bar (light green). Note that variants at position 2617 (known RNA-DNA differences) are not included. 

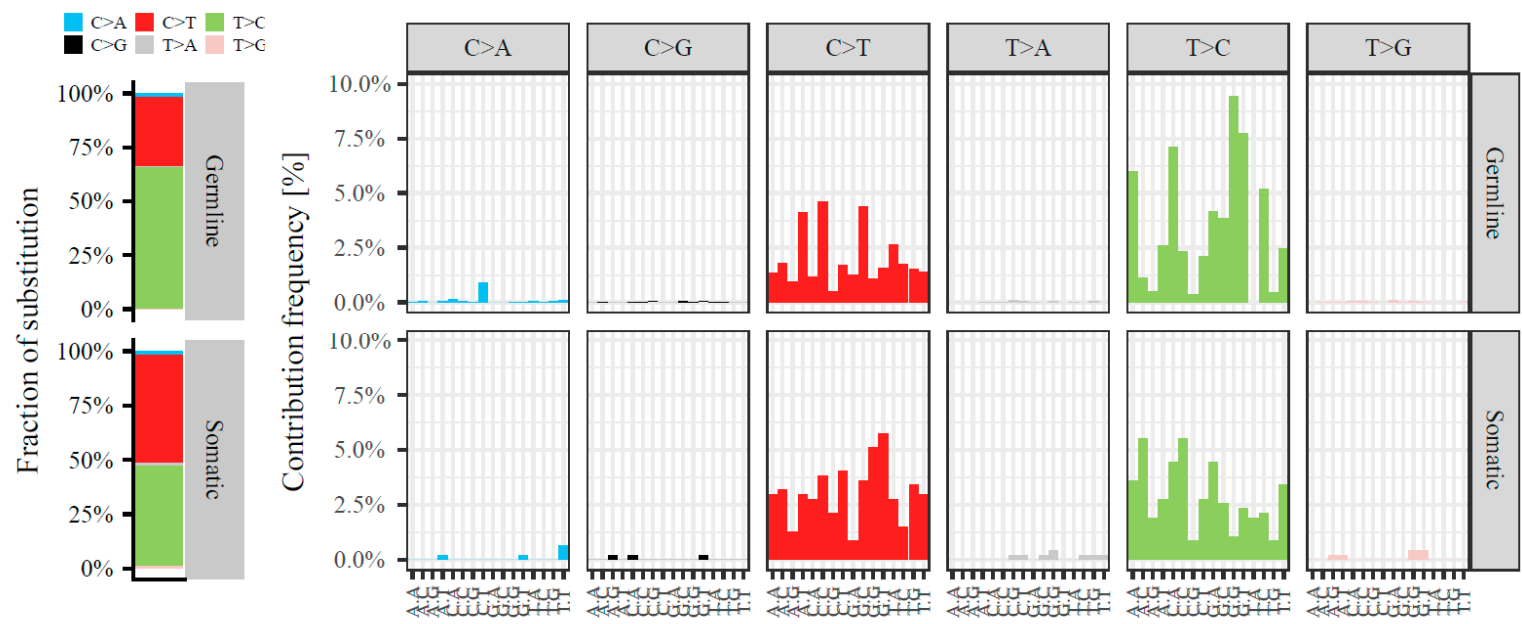

Motif

Figure 4. Somatic spectrum of mitochondrial RNA variants of 344 primary breast tumor cases. The contribution of the six possible base substitutions ( $\mathrm{C}>\mathrm{A}$ in blue, $\mathrm{C}>\mathrm{G}$ in black, $\mathrm{C}>\mathrm{T}$ in red, $\mathrm{T}>\mathrm{A}$ in grey, $\mathrm{T}>\mathrm{C}$ in green and $\mathrm{T}>\mathrm{G}$ in pink) (left) and the context of each substitution (bases immediately $5^{\prime}$ and $3^{\prime}$ to each variant in the reference genome) (right) are depicted for the germline (top) and somatic (bottom) variants (left). Note that variants on position 2617 (known RNA-DNA differences) are not included.

\subsection{Somatic Mitochondrial Variants in Relation to Somatic Variants in the Nuclear Genome}

Next, to gain more insight into the relation between the mutational processes shaping mtDNA and nDNA, we associated the amount of somatic mtRNA variants with the number of somatic variants induced by the known major mutational patterns shaping the nDNA. For this purpose, we obtained for the overlapping cases $(n=268)$ the number of nDNA variants as published by Nik-Zainal et al. [17]. There was no statistically significant association between the number of somatic mtRNA variants and the total number of somatic variants in the nuclear DNA (Spearman correlation coefficient rho $=0.01$, $p=0.8$ ). Next, we combined per case the number of variants in nDNA associated with the mutational processes as described by Nik-Zainal et al. [17]: age-related (signatures 1 and 5), APOBEC-related (signatures 2 and 13) and homologous-recombination deficiency-related (signatures 3 and 8) processes. No statistically significant associations were observed between the number of somatic mtRNA variants and any of these three mutational processes (all Kruskal-Wallis $p>0.2$ ). Note that only two samples within the dataset contained variants associated with mismatch-repair deficiency (signatures 6, 20 and 26), and none of samples contained variants associated with the signatures of unknown etiology (signatures 17, 18 and 30), as a consequence of which these specific subgroups could not be evaluated.

\subsection{Mitochondrial Gene Expression}

To estimate the expression and transcript processing of the mitochondrial genome for each case, transcripts per million (TPM, log2-transformed) were calculated for the entire mtDNA and each mitochondrial-encoded gene individually. Expression of the entire mtDNA-normalized against the nuclear genome and thus evaluated as driven by mtDNA content and transcription rate-was high and showed minor variability among the 344 cases (median 19.9210 TPM, IQR 0.0045). Within the 37 mitochondrial-encoded genes-normalized within the mitochondrial genome and thus evaluated as driven by processing of the polycistronic transcripts-the levels for genes encoding tRNAs were lowest (median 12.52 TPM, IQR 1.32), followed by mRNAs (median 15.37 TPM, IQR 0.31) and rRNAs (median 16.83 TPM, IQR 0.48). Most variability was observed in levels of tRNAs. Also, distinct correlation clusters were observed between the expression levels of the genes encoding mRNAs, tRNAs and rRNAs, where among genes a positive correlation was present per gene-type, but between different gene-types a negative correlation was present (Figure 5). No correlation was observed between the 
number of mtRNA variants and expression of the entire mtDNA (Spearman correlation coefficient rho $=-0.02, p=0.7)$.
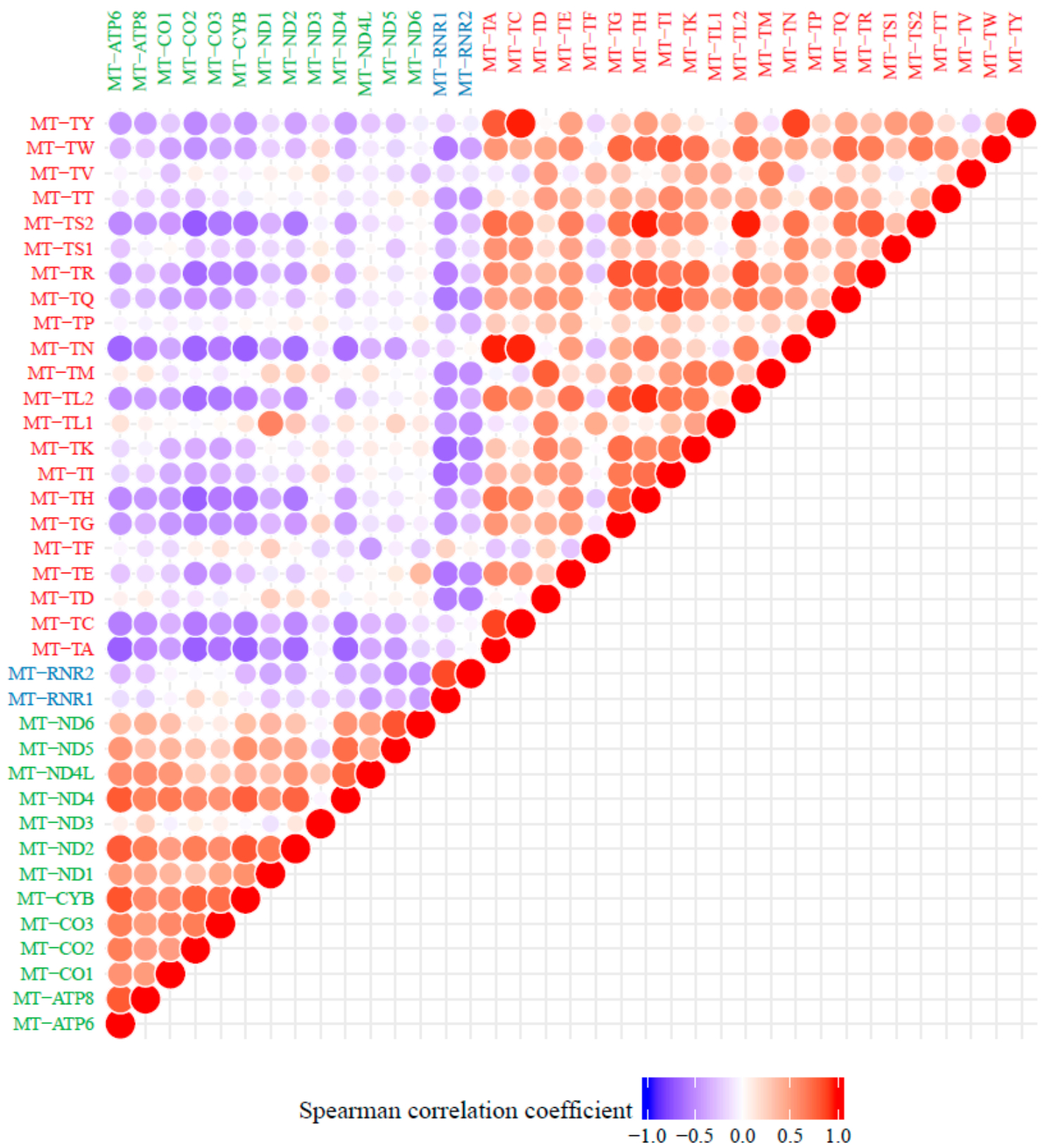

Figure 5. Correlation matrix of expression of all 37 mitochondrial-encoded genes of 344 primary breast tumor cases. Correlation matrix depicting the Spearman correlation between all 37 mitochondrial-encoded genes (text of tRNA genes in red, rRNA genes in blue, mRNA genes in green). Color intensity and the size of the circle are proportional to the correlation coefficients.

\subsection{Association with Clinicopathological Parameters}

Lastly, we explored how these findings correlate with relevant clinical parameters. We analysed the number of somatic mtRNA variants (grouped variable as 0 variants, 1 variant and $>1$ variant per tumor, Table 1) and the expression of the entire mitochondrial contig (continuous variable, Table 1 ) in relation to traditional clinicopathological variables including age at diagnosis ( $n=291$ cases), tumor size (T-stage) ( $n=216$ cases), pathological grade ( $n=282$ cases), estrogen receptor (ER) status ( $n=291$ cases) and progesterone receptor (PR) status ( $n=288$ cases). Due to the low numbers of 
patients with HER2-amplified ( $n=2$ cases) and presenting with metastases at primary diagnosis ( $n=3$ cases), these clinicopathological variables were not evaluated. Age at diagnosis was statistically significant associated with both the number of somatic mtRNA variants (Kruskal-Wallis $p=0.022$ ) and expression of the entire mtDNA (Spearman correlation coefficient rho $=0.11, p=0.049$ ), where a higher age corresponded to more somatic mtRNA variants and higher expression of the entire mtDNA. Also, a highly statistically significant association was observed between expression of the entire mtDNA and hormone receptor status (as evaluated at the protein level), with increased mtDNA expression in the ER-positive and in the PR-positive tumors (respectively Mann-Whitney $\mathrm{U}$ test $p<0.001$ and $p=0.006$ ). In fact, also a significant correlation was observed between expression of the entire mtDNA and RNA expression of ESR1 or PGR (respectively Spearman correlation coefficient rho $=0.19 p<0.001$ and rho $=0.17 p=0.001, n=344$ and $n=342$ cases).

Table 1. Association between number of somatic tumor mtRNA variants or expression of the entire mtDNA and clinicopathological variables.

\begin{tabular}{|c|c|c|c|c|c|c|c|}
\hline \multirow{2}{*}{ Variable } & \multirow{2}{*}{ No. of Cases } & \multicolumn{3}{|c|}{ mtRNA Somatic Variants } & \multirow{2}{*}{$p$} & \multirow{2}{*}{$\begin{array}{l}\text { mtRNA Expression } \\
\text { Median (IQR) TPM }\end{array}$} & \multirow{2}{*}{$p$} \\
\hline & & 0 Variants & 1 Variant & $>1$ Variants & & & \\
\hline $\begin{array}{c}\text { Age } \\
56(28-85) \\
\text { unknown }\end{array}$ & $\begin{array}{c}291(100 \%) \\
53\end{array}$ & $53(17)$ & $55(23)$ & $61(24)$ & $0.022^{a}$ & $0.11^{\mathrm{c}}$ & $0.049^{d}$ \\
\hline $\begin{array}{l}\text { Tumor size } \\
\text { T1 } \leq 2 \mathrm{~cm} \\
\text { T2 }>2-5 \mathrm{~cm} \\
\text { T3 }>5 \mathrm{~cm} \\
\text { unknown }\end{array}$ & $\begin{array}{c}76(35.2 \%) \\
109(50.5 \%) \\
31(14.4 \%) \\
128\end{array}$ & $\begin{array}{l}33.8 \% \\
47.9 \% \\
18.3 \%\end{array}$ & $\begin{array}{l}25.0 \% \\
64.1 \% \\
10.9 \%\end{array}$ & $\begin{array}{l}44.4 \% \\
42.0 \% \\
13.6 \%\end{array}$ & $0.07^{b}$ & $\begin{array}{l}19.9202(0.0043) \\
19.9207(0.0045) \\
19.9223(0.0047)\end{array}$ & $0.051^{\mathrm{a}}$ \\
\hline $\begin{array}{c}\text { Grade } \\
\text { I } \\
\text { II } \\
\text { III } \\
\text { unknown }\end{array}$ & $\begin{array}{c}24(8.5 \%) \\
111(39.4 \%) \\
147(52.1 \%) \\
62\end{array}$ & $\begin{array}{r}9.9 \% \\
40.7 \% \\
49.5 \%\end{array}$ & $\begin{array}{l}12.2 \% \\
35.1 \% \\
52.7 \%\end{array}$ & $\begin{array}{c}5.1 \% \\
41.0 \% \\
53.8 \%\end{array}$ & $0.4^{\mathrm{b}}$ & $\begin{array}{l}19.9202(0.0037) \\
19.9216(0.0044) \\
19.9209(0.0049)\end{array}$ & $0.1^{\mathrm{a}}$ \\
\hline $\begin{array}{c}\text { ER } \\
\text { Negative } \\
\text { Positive } \\
\text { unknown }\end{array}$ & $\begin{array}{c}81(27.8 \%) \\
210(72.2 \%) \\
53\end{array}$ & $\begin{array}{l}21.7 \% \\
78.3 \%\end{array}$ & $\begin{array}{l}31.2 \% \\
68.8 \%\end{array}$ & $\begin{array}{l}30.3 \% \\
69.7 \%\end{array}$ & $0.3^{b}$ & $\begin{array}{l}19.9196(0.0050) \\
19.9216(0.0041)\end{array}$ & $<0.001^{a}$ \\
\hline $\begin{array}{c}\text { PR } \\
\text { Negative } \\
\text { Positive } \\
\text { unknown }\end{array}$ & $\begin{array}{c}102(35.4 \%) \\
186(64.6 \%) \\
56\end{array}$ & $\begin{array}{l}31.5 \% \\
68.5 \%\end{array}$ & $\begin{array}{l}40.5 \% \\
59.5 \%\end{array}$ & $\begin{array}{l}35.0 \% \\
65.0 \%\end{array}$ & $0.5^{b}$ & $\begin{array}{l}19.9204(0.0048) \\
19.9215(0.0042)\end{array}$ & $0.006^{\mathrm{a}}$ \\
\hline
\end{tabular}

\section{Discussion}

In this work, we explored genomic changes in and expression of the mitochondrial genome within primary breast tumors, and their correlation with clinicopathological variables.

Within our breast tumor dataset, the fraction of reads mapping to the mitochondrial contig of the reference genome (median 15\%) is in line with previous findings in non-tumorous breast samples: within the Illumina Body Tissue Atlas $\sim 15 \%$ of the sequencing reads mapped to the mitochondrial genome $(n=1)$ [22], and within the Genotype-Tissue Expression (GTEx) Consortium 15-20\% of the transcriptional output was of mitochondrial origin $(n=27)$ [23]. This is in line with the requirement for functional mitochondria within cancer cells [24]. This also indicates that although the expression of the mitochondrial genome has been shown to be decreased in breast tumors compared to tumor-adjacent normal mammary tissue [11], the extent to which this occurs is less extreme than observed among tissue types (e.g., a much lower fraction of mitochondrial reads in blood $(<5 \%)$ or much higher fraction in kidney (>50\%) [23]). Nevertheless, we observed an association between expression of the entire mtDNA and ER status (measured at protein-level), with marginally higher expression in ER-positive tumors and a similar observation for PR status (protein-level) (Table 1). In addition, also RNA 
expression of ESR1 and PGR was positively correlated with expression of the entire mitochondrial contig. The relation between expression of mtDNA and clinicopathological parameters has not been evaluated by others, but when we associated the data reported by Reznik et al. [11] on mtRNA expression within the TCGA-BRCA dataset ( $n=656$ cases) we observe a similar correlation for ER status (Kruskal-Wallis $p=0.006$, Supplementary Materials Table S2 and none for the other clinicopathological variables (all $p>0.05$ Supplementary Materials Table S2). In pre-clinical models, there appears to be a link between ER and mitochondrial activity: exposure to estrogens increases mitochondrial expression and oxygen consumption in ER-positive $[25,26]$ but not in ER-negative breast cancer cells [26]. Similarly, ER-negative breast cancer cell lines show lower mitochondrial respiration and a stronger dependency on glycolysis in comparison to ER-positive breast cancer cells [27]. Unfortunately, measurements on mitochondrial activity comparing ER-positive and ER-negative clinical specimens are to our knowledge not reported in the literature, and thus the effect of differences in ESR1 levels on mitochondrial activity in primary breast tumors remains currently unknown. Interestingly, uptake values of fluorodeoxyglucose (FDG) in positron emission tomography (PET) - a visualization of glucose uptake reflecting the increased rate of glycolysis in the tumor-appears to be higher in ER-negative cases [28-34], indicative that indeed metabolic differences are present between the subtypes. Additional studies should be performed to identify if there are differences in mitochondrial (oxidative phosphorylation) function among breast cancer subtypes and the potential clinical relevance of these findings, such as predictive and prognostic potential.

We also observed distinctive clustering of tRNA genes, which is in line with the tRNA punctuation model: when processing the polycistronic transcripts, tRNA genes are excised and due their small size ( $<75$ base pairs) tRNAs are more likely to be lost during the RNA extraction and/or library preparation procedures, whereas the mRNA and rRNA genes are retained ( $>200$ base pairs). Notably, we did not observe differences in this distinct pattern between the ER-positive and the ER-negative cases (Supplementary Materials Figures S2 and S3), and thus the processing of the polycistronic transcripts does not seem to differ between these two subtypes.

Our findings on the number, genomic distribution, and substitution pattern of mtDNA variants within the mitochondrial transcriptome are in line with previous studies on variants within the mitochondrial genome in other cancer types $[8,15,16,21,35,36]$ (see also Appendix A). We observe an increased number of somatic variants in the D-loop and fewer in mRNA genes than expected by genomic size, which might be explained by the gene-dense constitution of mtDNA: variants in the D-loop potentially have less destructive effects whereas variants in the mRNA genes might have detrimental effects on the function of the oxidative phosphorylation system, and thus will be selected against. Also, the structural conformation of the D-loop (a triple-stranded structure) could make it more prone to damage. However, compared to germline variants in our dataset there are fewer variants in the D-loop and more in the tRNA and mRNA genes, and enrichment for nonsynonymous variants. This might be explained by the typical mutation pattern shaping $\mathrm{mtDNA}$, which has been shaping the germline variants and thus the trivial positions have already been altered, as suggested by Ju et al. [15]. In line with this, the conservation of variants among species-the fraction of species that harbor the reference sequence at that position —-was much higher for somatic variants than for the germline variants, which can be explained by the same hypothesis. Adding to this, compared to the detected germline variants there is an increased number of $C>T$ transitions among the somatic variants (Figure 4). Note that the functional effect of somatic mtDNA variants on mitochondrial function is dependent on the actual position (e.g., protein-coding regions) and consequence (e.g., stop-gain or nonsynonymous) of the variant in combination with their heteroplasmy level within the tumor cell, rather than merely the number of somatic variants observed.Adjusting variant allele frequency to account for sample purity (percentage of tumor cells within the specimen) is often applied for nuclear-encoded genes to obtain information on the allele frequency of variants in the tumor cells. However, this is not possible for mtDNA variants in tumor tissue specimens: the number of mtDNA molecules per cell largely varies among cell types and thus the non-tumor cells present in the specimen 
do not have the regular two copies as the nuclear genome would have, but contain multiple mtDNA copies of an unknown number. As a result, whereas allele frequency of variants could give information on possible constraints on variants, we did not perform analysis on it since it is impossible to estimate the actual allele frequency of variants in the mitochondria of tumor cells. Nevertheless, we show that majority of the samples with more than 1 somatic variant harbor a difference in variant allele frequency between variants, indicative for (sub-)clonality. This corresponds to the hypothesis that mtDNA variants are either expanded or lost [37] and that the mutations occur separated in time [15].

Also noteworthy is that with the current methodologies applied by us and by others-namely the use of non-micro dissected tumor specimens and blood as matched normal DNA-we cannot be completely sure that the detected somatic mtDNA mutations are tumor-specific. First, tumor tissue specimens consist of multiple cell types, including the tumor cells but also non-neoplastic cells such as immune cells and cells from the mammary epithelium, all with variable mtDNA content. Secondly, (somatic) mtDNA variant heteroplasmy patterns can differ within an individual across tissues [38-41]. Thus, the somatic variants were either acquired in the tumor, the normal somatic epithelium, or even in other cell types present within the specimen.

We did not observe associations between the number of somatic mtRNA variants and the three major mutational processes shaping the nDNA within breast tumors. This is in line with the hypothesis that mutations within the mitochondrial genome are mainly due to fidelity of the mitochondrial polymerase [42] and thereby hardly due to exogenous factors [15]. Accordingly, in our evaluation of associations with clinicopathological parameters we observed a statistically significant association between the number of mtRNA somatic variants and age at diagnosis. Previous work on somatic variants at the DNA level also revealed a correlation with older age of diagnosis ( $n=381$ [15] and $n=58$ cases [35]). Previous work in a small cohort also showed associations between number of somatic variants in mtDNA and higher TNM and higher histological grade $(n=58$ cases [35]), which we did not observe. Please note that there are differences in the composition of the cohorts; our dataset does not exactly represent the breast cancer population as seen in daily practice, with an underrepresentation of ERBB2-amplified cases (Supplementary Materials Table S3).

By using data at the RNA level, we intended to minimize the interference of NUMTs with evaluation of mtDNA expression and variant calling, since their expression in the nucleus is negligibly low [11,43]. Especially in defining heteroplasmic mtDNA variants in DNA data, NUMTs have been shown to be a complicating issue with non-identical positions misinterpreted as heteroplasmic variants [44-48]. Note that we do observe a few heteroplasmic variants at the DNA-only level (Appendix A). However, using data at the RNA level comes with the trade-off that only variants in expressed regions are detected and thus variants in non-expressed regions are missed. Since mtDNA is a gene-dense entity, we estimate that the number of missed variants should be low. Indeed, in our direct comparison of samples with variants at the RNA and DNA level, we show that this is maximally $\sim 3 \%$ of the variants (DNA-only variants). Similar to these findings, the comparison by Stewart et al. [16] on somatic variants at the RNA and DNA level showed 7 of the 130 variants (5\%) detected at only the DNA level within their set of 100 breast cancer specimens. Another trade-off using RNA is the additional step to generate cDNA, which might induce false positive calls by mistakes of the reverse transcriptase. Again based on our direct comparison of samples with variants at the RNA and DNA level, the number of false positives is maximally $3 \%$ of the detected variants (RNA-only variants). Though, besides false positives, these RNA-only variants might actually be RNA-DNA differences for example caused by RNA-editing [49], or true variants not called at the DNA level.

\section{Materials and Methods}

\subsection{Data}

We studied all patients with RNA sequencing data within the ICGC BASIS consortium, of which the cohort has been described previously [17] and data deposited in the European-Genome Phenome 
Archive (accession code EGAS00001001178). Briefly, for a total of 348 primary breast tumors we generated duplex-specific nuclease-based RNA sequencing data. Four samples were excluded from analyses due to potential cross-contamination (see below). We did not apply a threshold on tumor cell percentage within the specimen for inclusion in this study. Clinicopathological data and the nuclear somatic mutation catalogue were obtained from the Supplementary Tables as provided by Nik-Zainal et al. [17]. Expression levels of ESR1, PGR (quantile normalized FPKM, log2 transformed) were obtained as described previously [50]. A complete dataset on all variables used in our analyses is provided in Supplementary Materials Table S3. In addition, we used publically available RNA sequencing data of twelve human tissue specimens obtained via a similar sequencing approach [20], that has been deposited in NCBI's Gene Expression Omnibus (GEO) (accession code GSE45326). Also, we used the mtDNA variants called by Ju et al. [15] from whole-genome or whole-exome sequencing data of DNA from the primary breast tumor specimens and matched normal tissue specimens as provided in their Supplementary Tables.

\subsection{Bioinformatics}

Sequencing reads were aligned using STAR v2.4.2.a [51] against the Genome Reference Consortium Human Build 38 (GRCh38, GenBank assembly GCA_000001405.15), which contains as the mitochondrial contig the revised Cambridge Reference Sequence (rCRS). Only non-duplicated uniquely mapped reads on mtDNA were used for further analysis, to avoid the potential use of improper assigned nuclear insertions of mitochondrial origin (NUMTs, mitochondrial pseudogenes). Note that RNA expression of NUMTs has been shown to be absent or negligibly low $[11,43]$. Total read depth was estimated based on the read length (75 nucleotides) and mtDNA size $(16,569$ nucleotides). FeatureCounts $\mathrm{v}$ 1.4.6 [52] was used to count mapped reads using mtDNA as the meta-feature and each genomic region (13 mRNAs, 22 tRNAs, 2 rRNAs) as the features, allowing multi-overlapping reads $(-\mathrm{O})$ because of the polycistronic nature of mitochondrial RNA transcripts. We normalized read counts to transcripts per million (TPM) for the entire mitochondrial contig (mtDNA read counts versus total read counts assigned to genes in GRCh38, defined as entire mtDNA levels) and for each mitochondrial-encoded gene (gene read counts versus total mtDNA read counts, defined as <gene> levels). In this way, the TPM for the entire mtDNA represents the total amount of mtRNA influenced by both mtDNA content, transcription rate and transcript stability, whereas the TPM for each mitochondrial-encoded gene represents the variation in gene expression driven by processing of the polycistronic transcripts and transcript stability [53]. A complete dataset of all expression levels is provided in Supplementary Materials Table S4. Variants alternative to rCRS were called using GATK HaplotypeCaller 3.4-46-gbc02625 [54] using default settings (including downsampling_type = BY_SAMPLE, downsample_to_coverage = 500 , standard_min_confidence_threshold_for_calling $=20$ ). In this way, maximum depth of coverage is controlled at each locus, resulting in a more even coverage of variants between the samples. Hard-filtering was applied to the called variants for quality by depth (QD > 2), alternative depth (AD of ALT $>10$ ) and strand odds ratio (variants with allele frequency $\leq 95 \%$ i.e., heteroplasmic variants: SOD $<4$ for SNVs and SOD $<10$ for INDELs; variants with allele frequency $>95 \%$ i.e., (near) homoplasmic: no filtering). In this way, the allele frequency of detected variants was high and confident enough to be a true variant and likely no sequencing errors or PCR mistakes. In addition, after visual inspection of variants (Integrative Genomics Viewer $[55,56]$ ), potential false positive calls in challenging regions were excluded: positions surrounding the homopolymer region 301-315 ("D310"), positions 512-513 due to a repetitive sequence, alternative $C$ calls at positions $16,182-16,183$ and 16,189 due to polyC sequences, and alternative $\mathrm{A}$ at positions 4264,5513 and 12,138-12,139 due to polyA sequences. A complete dataset of all remaining variants is provided in Supplementary Materials Table S5. All remaining single nucleotide variants were used in a nucleotide BLAST against the human reference sequence (NCBI's nucleotide web blast, https:/ /blast.ncbi.nlm.nih.gov) with the surrounding reference sequence ( 30 bases $5^{\prime}$ and 30 bases $3^{\prime}$ ) to uncover potential NUMT events, but 
none were recovered. The conservation index (45 species conservation) for the protein-coding genes, tRNAs and rRNAs were obtained via SNV Query in Mitomaster [57]. The haplotype of each case was estimated by using the heteroplasmic and homoplasmic variants in HaploGrep v2 [58]. Sample cross-contamination was estimated using only the heteroplasmic variants (allele frequency $\leq 95 \%$ ) in haplotype assignment. This identified four samples with heteroplasmic contamination of another haplotype, therefore these samples were excluded from analyses. Sample mismatch between cases with variants called in both RNA (our dataset) and DNA (dataset Ju et al. [15]) sequencing data $(n=168)$ was estimated by haplotyping based on all near-homoplasmic variants (allele frequency $>95 \%$ ), and comparison of the obtained haplogroup. Mismatch was observed for 13 patients, but after manual inspection specificity could be confirmed for 10 patients by the presence of private variants. Two patients with a clear mismatch, and one patient ambiguous in mismatch, were excluded from the RNA-DNA comparison analyses ( $n=165$ remaining).

\subsection{Statistics}

Performed statistical tests are reported in the results section. All statistical tests were two-sided, and $\mathrm{P}$ values smaller than 0.05 were considered as statistically significant. Outliers data points in boxplots are defined as Q1-1.5*IQR or Q3+1.5*IQR. Analyses were performed in $\mathrm{R}$ version 3.3.2 (https://cran.r-project.org). Data analyses included usage of the following packages: the set of tidyverse, ggcorplot, SomaticSignatures [59] and VennDiagram [60].

\section{Conclusions}

To conclude, in this explorative study on the role of mtRNA in breast cancer, we found that somatic variants at the DNA level are reflected at the RNA level with no hotspot mutations and great heterogeneity across tumors. We confirm that the number of somatic variants within the mitochondrial transcriptome is not associated with the mutational processes shaping the nuclear genome but instead, is associated with age of diagnosis. Furthermore, we show that mitochondrial expression is related to ER status. The exact consequence of the observed differences in mtRNA expression and the detected somatic variants on cancer metabolism and clinical outcome warrants further study.

Supplementary Materials: The following are available online at http://www.mdpi.com/2072-6694/10/12/ 500/s1, Figure S1: Histogram of variant allele frequency of the somatic mitochondrial RNA variants of 344 primary breast tumor cases, Figure S2: Correlation matrix of expression of all 37 mitochondrial-encoded genes of 81 ER-negative primary breast tumor cases, Figure S3: Correlation matrix of expression of all 37 mitochondrial-encoded genes of 210 ER-positive primary breast tumor cases, Table S1: Position 2617 in normal tissue specimens, Table S2: Association between mtRNA expression and clinicopathological variables in TCGA-BRCA, Table S3: Clinicopathological and other variables per sample ( $n=344$ cases), Table S4: Expression levels of mtRNA per sample ( $n=344$ cases), Table S5: Variants in mtRNA per sample $(n=344$ cases).

Author Contributions: Conceptualization, M.J.A.W., M.S., J.A.F., S.S. and J.W.M.M.; Formal analysis, M.J.A.W. and M.S.; Funding acquisition, J.W.M.M.; Methodology, M.J.A.W. and M.S.; Supervision, J.A.F., S.S. and J.W.M.M.; Writing—original draft, M.J.A.W.; Writing—review \& editing, M.J.A.W., M.S., J.A.F., S.S. and J.W.M.M.

Funding: The data used in this work has been funded through the ICGC Breast Cancer Working group by the Breast Cancer Somatic Genetics Study (BASIS) (FP7/2010-2014, grant agreement number 242006) and the Triple Negative project (Wellcome Trust grant reference 077012/Z/05/Z).

Acknowledgments: We acknowledge all members of the ICGC Breast Cancer Working Group.

Conflicts of Interest: The authors declare no conflict of interest.

\section{Appendix A}

\section{Appendix A.1. Comparison of Mitochondrial Variants at the RNA and DNA Level}

By using the dataset published by Ju et al. [15] concerning somatic mitochondrial variants in tumor and matched normal specimens at the DNA level, we intended to compare mitochondrial variants called in primary breast tumor tissue specimens at the RNA and the DNA level. Their dataset 
includes a total of $n=381$ breast tumor specimens, of which $n=165$ cases are overlapping with our dataset.

The DNA dataset contains 8892 single nucleotide variants (SNVs) on 1744 positions within the 381 cases (Figure A1), of which 589 variants classified as somatic (using VarScan2, see Ju et al. [15]).

- Germline

- Somatic

\section{Position on $m t D N A$}

$1 / 16569$

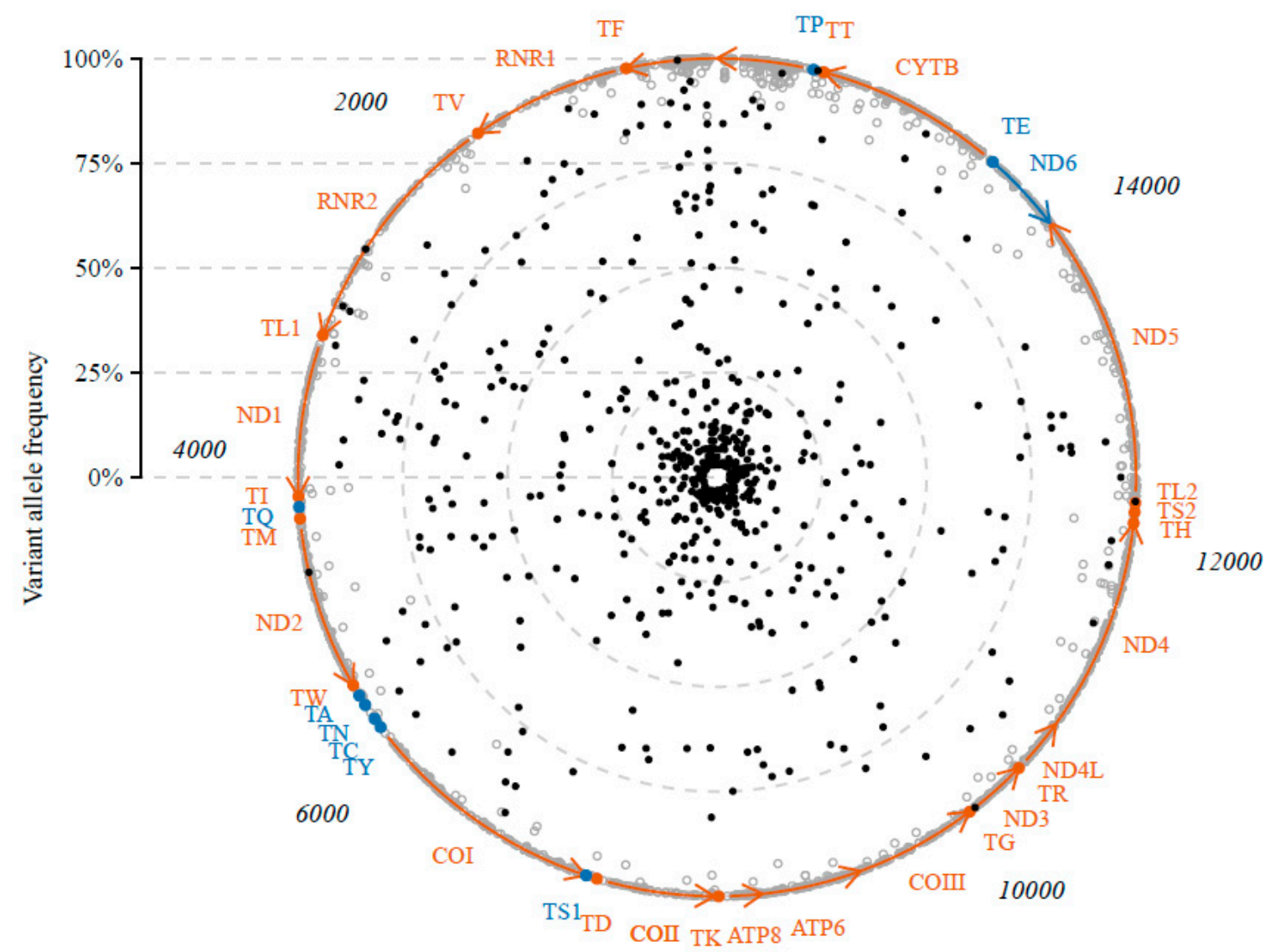

8000

Figure A1. Variants in the mitochondrial DNA of 381 primary breast tumor cases. Position on the mitochondrial genome (circle) and their variant allele frequency (increasing \% from inner-to-outer) of all variants identified in the 381 cases. Somatic or germline origin in respectively closed black or open grey circles. Genes and their direction of transcription (arrows) in red (+strand) or blue (-strand).

The variant allele frequency of these somatic variants was distributed with a peak at the lower end of allele frequencies (Figure A2). The detected somatic variants were distributed along the entire mitochondrial genome (Figure A1), with $50(8.5 \%)$ variants located in the tRNA genes, $103(17.5 \%)$ in rRNA genes, $80(13.6 \%)$ in the D-loop, $6(1.0 \%)$ in the non-coding regions, and $350(59.4 \%)$ in the mRNA genes of which 285 (81.4\%) had a nonsynonymous effect on the coding amino acid (Figure A3). Relative to their genomic size $(9.0 \%$ tRNA genes, $15.1 \%$ rRNA genes, $6.8 \%$ D-loop, $0.4 \%$ non-coding, $68.7 \%$ mRNA genes) more variants were present in the D-loop and fewer in the mRNA genes (Fisher exact $p<0.001$ ). Also compared to the germline variants, there is a difference in genomic distribution: fewer somatic variants in the D-loop but more in the tRNA and mRNA genes, and an enrichment for somatic nonsynonymous mRNA variants (Fisher exact $p<0.001$ ) (Figure A3). The positions of somatic variants were much more conserved among species compared to the germline variants (Mann-Whitney 
test $p<0.001)$, as measured by the fraction of species that harbor the reference sequence at that position (Conservation Index of respectively median (IQR) $0.96(0.36)$ and $0.76(0.69)$ ).

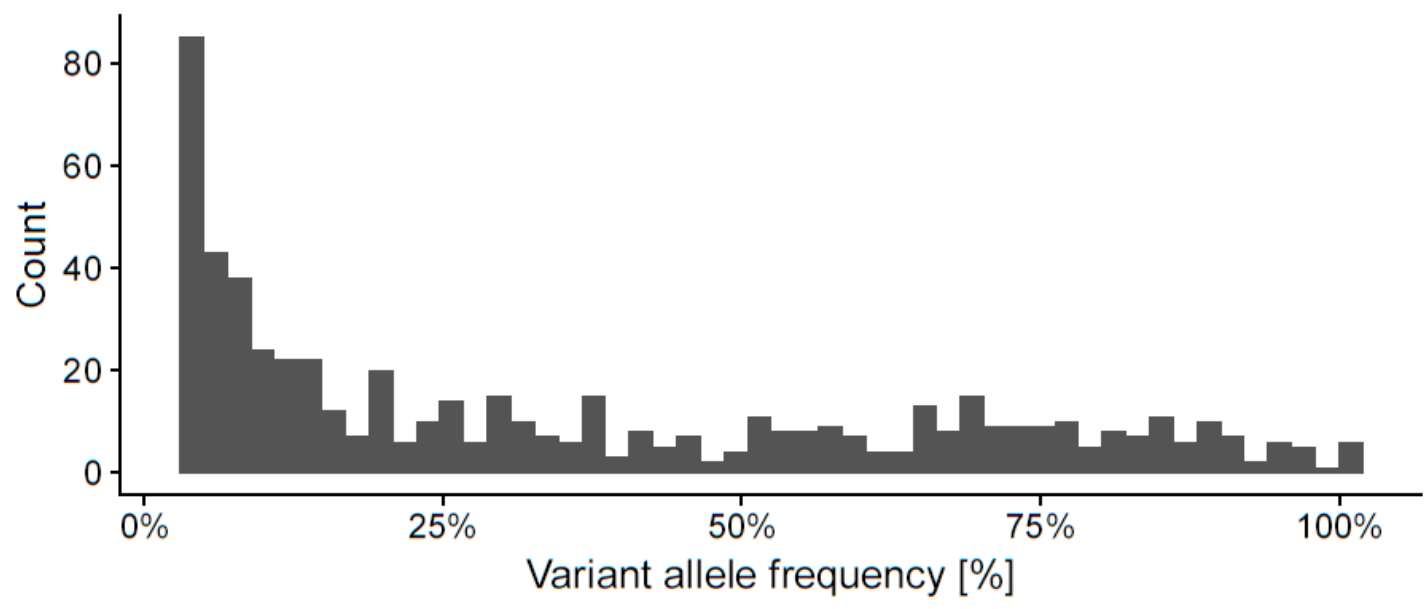

Figure A2. Histogram of variant allele frequency of the somatic mitochondrial DNA variants of 381 primary breast tumor cases. Histogram of the variant allele frequency (horizontal) of the somatic mitochondrial DNA variants detected in the 381 primary breast tumor cases.

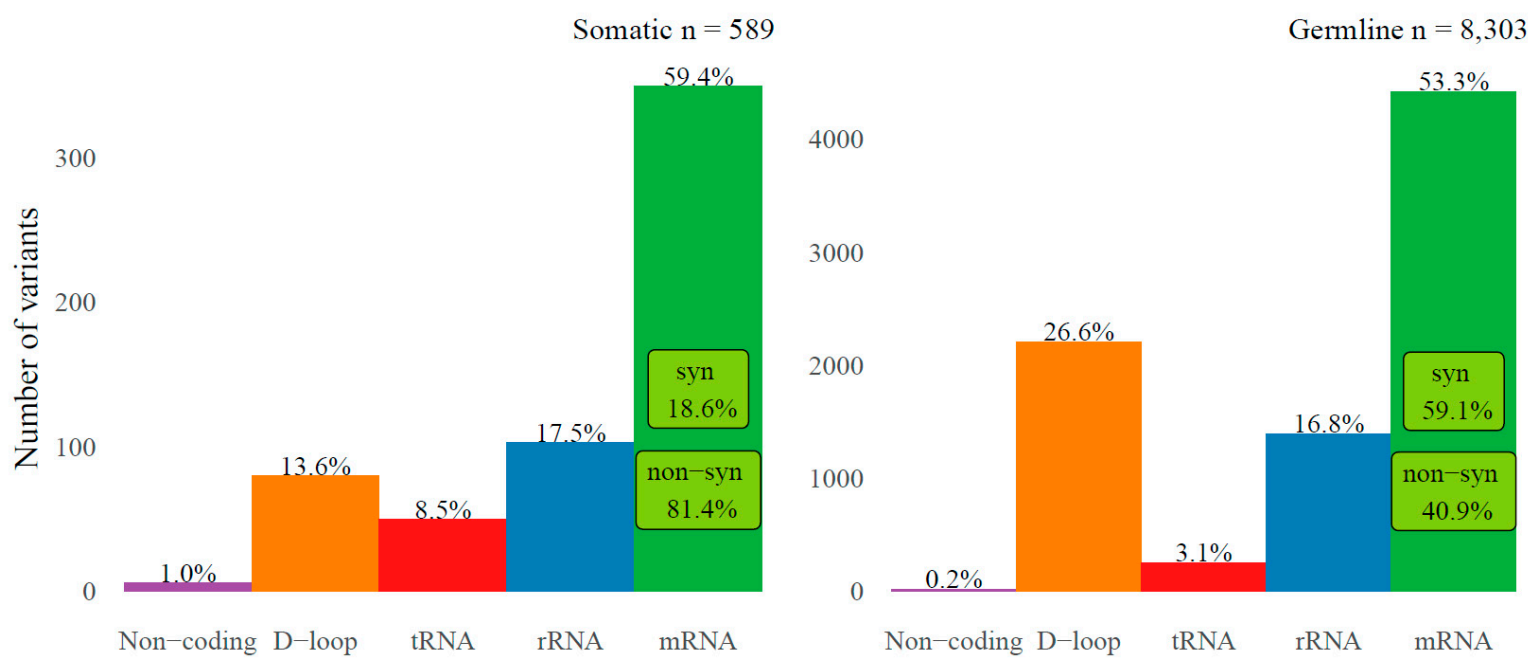

Figure A3. Genomic distribution of mitochondrial DNA variants of 381 primary breast tumor cases. Genomic distribution is depicted for somatic (left) or germline (right) variants in either non-coding (purple), the D-loop (orange), tRNA (red), rRNA (blue) or mRNA (green) regions of the mitochondrial genome. The percentage of total is indicated at the top of the bars. The percentage of substitutions in the mRNA regions with either a synonymous or nonsynonymous effect is indicated within the mRNA bar (light green).

A total of 74 (12.6\%) somatic variants were recurrent and positioned on 34 mitochondrial positions. Also, majority of the somatic variants $(89.5 \%)$ represented the typical replication-coupled mtDNA substitution pattern with predominantly $\mathrm{C}>\mathrm{T}$ and $\mathrm{T}>\mathrm{C}$ transitions in a nucleotide context similar to the germline variants (Figure A4). Compared to the detected germline variants the ratio between $C>T$ and $\mathrm{T}>\mathrm{C}$ variants is shifted (Fisher exact $p<0.001$ ) with an increased number of $\mathrm{C}>\mathrm{T}$ transitions among the somatic variants (Figure A4). In the cohort, there are $101(26 \%)$ cases with 0 somatic variants, 117 (31\%) with 1 somatic variant, and $163(43 \%)$ with more than 1 somatic variant (range 2 to 7$)$. Of the cases with more than 1 somatic variant, $103(63 \%)$ had a difference $>20 \%$ allele frequency between variants, indicative for (sub-)clonality. 
When comparing these findings at the DNA level with our findings at the RNA level, no differences were observed in genomic distribution of the somatic variants (Fisher's exact $p=0.1$ ), the conservation index of somatic variants (Mann-Whitney test $p=0.4$ ), and the recurrence rate (Fisher's exact $p=0.3$ ). However, the substitutional pattern differed, with a higher fraction of $C>A$ substitutions at the DNA level $(4.8 \%)$ compared to the RNA level (1.1\%) (Fisher's exact $p<0.001)$.
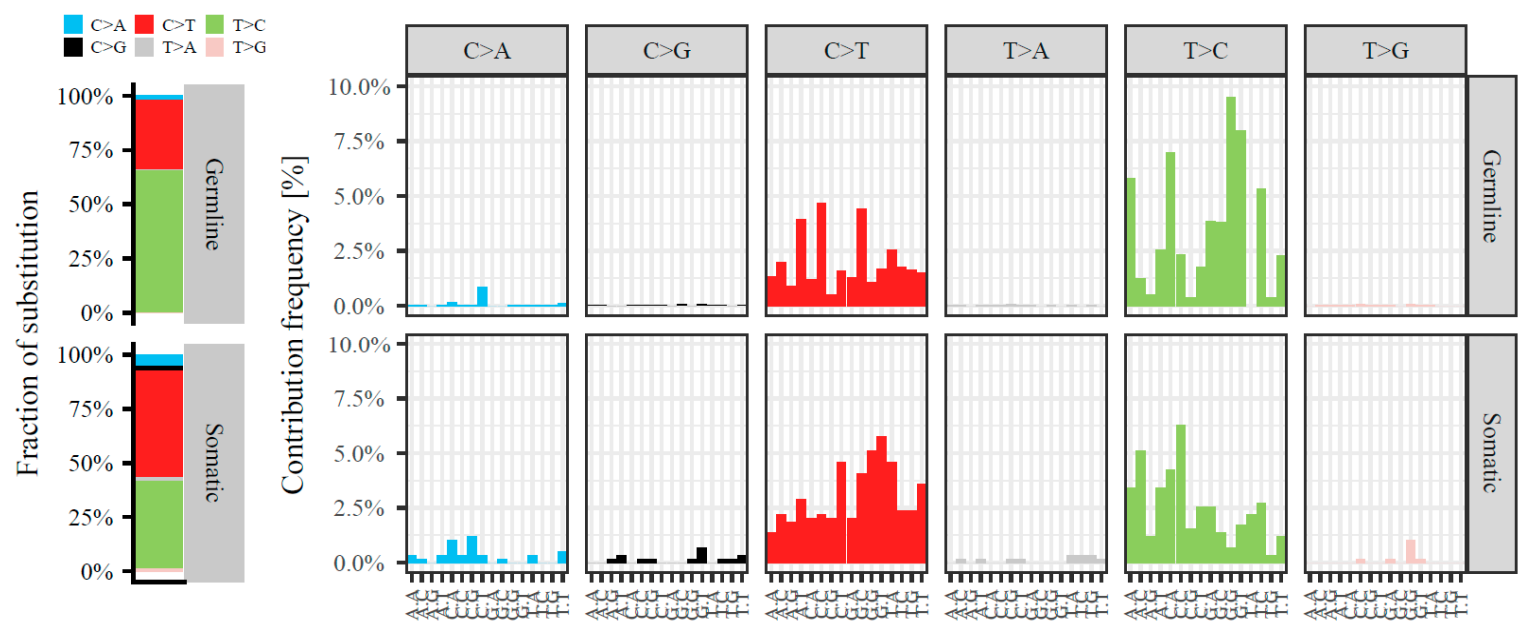

Motif

Figure A4. Somatic spectrum of mitochondrial DNA variants of 381 primary breast tumor cases. The contribution of the six possible base substitutions ( $C>A$ in blue, $C>G$ in black, $C>T$ in red, $T>A$ in grey, $\mathrm{T}>\mathrm{C}$ in green and $\mathrm{T}>\mathrm{G}$ in pink) (left) and the context of each substitution (bases immediately $5^{\prime}$ and $3^{\prime}$ to each variant in the reference genome) (right) are depicted for the germline (top) and somatic (bottom) variants (left).

\section{Appendix A.2. Direct Comparison of Mitochondrial Variants at the RNA and DNA Level of Overlapping Cases}

We next focused on the variants called within the overlapping cases within our RNA and the published DNA dataset ( $n=165$ cases). As stated in the main manuscript text, of the variants detected at both the RNA and DNA level only a few $(n=10,0.3 \%)$ had a discrepancy in classification as either 'somatic' or 'germline' (resp. $n=4$ and $n=6$, Table A1). These were misclassifications at the RNA level, mainly due to the absence of information on the matched normal tissue: variants misclassified as 'germline' at the RNA level had allele frequencies $>95 \%$, indicative for germline origin, but were not detected in the matched normal DNA whereas they were present in the matched tumor DNA and thus of somatic origin. Also, variants misclassified as 'somatic' at the RNA level had allele frequencies between $85 \%$ and $95 \%$ allele frequency, but were detected in the matched normal DNA as well as the matched tumor DNA and thus of germline origin. Also, of the variants detected at both the RNA and DNA level, only a few variants $(n=7,0.2 \%)$ showed a strong deviation in variant frequency $(>30 \%$ difference) ( $n=3$ germline and $n=4$ somatic) (Table A2). In contrast to previous observations that mainly variants in tRNAs have allelic imbalances [9], none of them occurred at tRNA sites.

We continued evaluating the variants called within the overlapping cases present at either only the DNA or only the RNA level. A total of 120 variants (3.0\%) were only called at the DNA level (103 somatic and 17 germline) (Table A2) and 108 variants (2.7\%) were present at only the RNA level (47 somatic and 61 germline) (Table A3). Within the aligned reads of the RNA data (BAM file) we inspected if variants called at the DNA-only level were truly not present at the RNA level or just not called (Table A2). Majority of the called DNA variants were present in the RNA alignment data but not called by our used algorithm ( $n=108,90 \%)$, a few variants were not (sufficiently) covered $(n=5,4 \%)$, and some were sufficiently covered but truly not present as alternative allele $(n=7,6 \%)$. Unfortunately, we were unable to visually inspect variants in the DNA alignment data (not available) and thus the relevance of variants present at only the RNA level was not evaluable. Interestingly, when evaluating 
the substitution pattern of variants detected at both the RNA and DNA level (Figure A5), and at either the RNA or DNA level, the higher fraction of C > A substitutions at the DNA level compared to the RNA level appeared mainly due to variants called at only the DNA level.

Given these results, the differences we observe in called variants at the RNA and DNA level is likely an effect of differences in either the expression at the RNA level (biological) the calling algorithms used (technical).

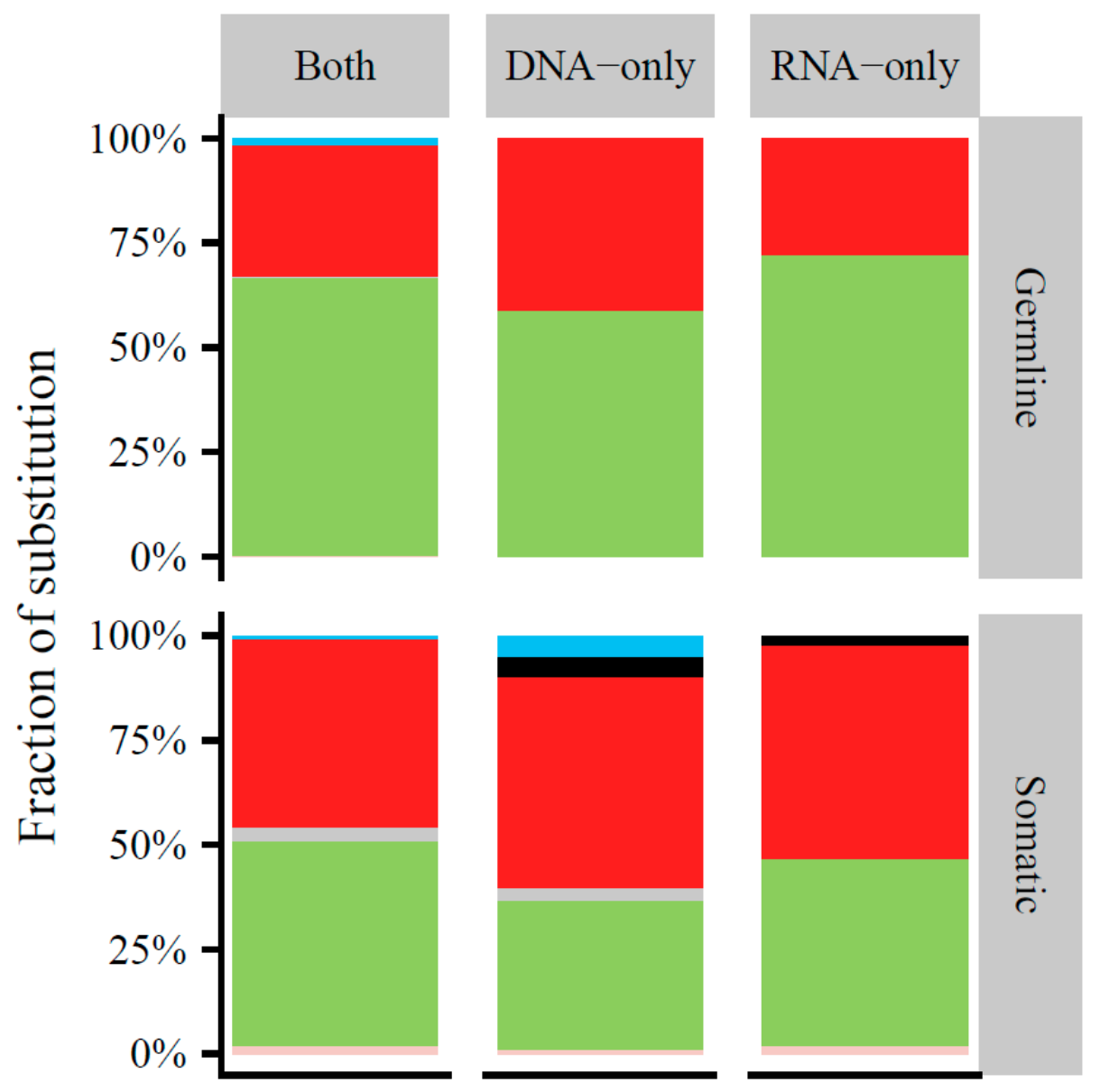

Figure A5. Somatic spectrum of mitochondrial DNA and mitochondrial RNA variants of the 165 overlapping primary breast tumor cases. The contribution of the six possible base substitutions $(\mathrm{C}>\mathrm{A}$ in blue, $\mathrm{C}>\mathrm{G}$ in black, $\mathrm{C}>\mathrm{T}$ in red, $\mathrm{T}>\mathrm{A}$ in grey, $\mathrm{T}>\mathrm{C}$ in green and $\mathrm{T}>\mathrm{G}$ in pink) are depicted for the germline (top) and somatic (bottom) variants detected in both (left) the DNA (middle) or the RNA (right) datasets. 
Table A1. Positions misclassified at RNA versus DNA.

\begin{tabular}{|c|c|c|c|c|c|c|c|c|c|c|}
\hline Sample & Variant & $\begin{array}{c}\text { Depth RNA } \\
\text { Tumor }\end{array}$ & $\begin{array}{c}\text { VAF RNA } \\
\text { Tumor }\end{array}$ & Class RNA & Variant & $\begin{array}{c}\text { Depth DNA } \\
\text { Tumor }\end{array}$ & $\begin{array}{c}\text { VAF DNA } \\
\text { Tumor }\end{array}$ & $\begin{array}{c}\text { Depth DNA } \\
\text { Normal }\end{array}$ & $\begin{array}{l}\text { VAF DNA } \\
\text { Normal }\end{array}$ & Class DNA \\
\hline P_6042a & r. $199 u>c$ & 1953 & $99.3 \%$ & Germline & g.199T>C & 6585 & $67.1 \%$ & 208 & $0.5 \%$ & Somatic \\
\hline P_9571a & r. $1010 a>c$ & 1655 & $97.1 \%$ & Germline & g.1010A $>C$ & 21,840 & $94.9 \%$ & 763 & $0.0 \%$ & Somatic \\
\hline P_6409a & r. $4344 \mathrm{u}>\mathrm{c}$ & 146 & $97.9 \%$ & Germline & g. $4344 \mathrm{~T}>\mathrm{C}$ & 16,068 & $68.9 \%$ & 1707 & $0.1 \%$ & Somatic \\
\hline P_6043a & $\mathrm{r} .5353 \mathrm{~g}>\mathrm{a}$ & 1099 & $97.6 \%$ & Germline & g.5353G > A & 20,514 & $88.0 \%$ & 544 & $0.0 \%$ & Somatic \\
\hline P_5956a & r. $11453 \mathrm{~g}>\mathrm{a}$ & 1655 & $96.6 \%$ & Germline & g.11453G >A & 21,214 & $96.3 \%$ & 4230 & $0.0 \%$ & Somatic \\
\hline P_9568a & r.14841a $>g$ & 1877 & $97.4 \%$ & Germline & g. $14841 \mathrm{~A}>\mathrm{G}$ & 12,060 & $86.5 \%$ & 806 & $0.1 \%$ & Somatic \\
\hline P_4982a & r. $94 \mathrm{~g}>\mathrm{a}$ & 698 & $91.1 \%$ & Somatic & g. $94 \mathrm{G}>\mathrm{A}$ & 9643 & $99.8 \%$ & 1449 & $99.5 \%$ & Germline \\
\hline P_4982a & r. $152 \mathrm{u}>\mathrm{c}$ & 614 & $93.0 \%$ & Somatic & g.152T >C & 11,738 & $99.8 \%$ & 2090 & $99.0 \%$ & Germline \\
\hline P_8622a & $\mathrm{r} .497 \mathrm{c}>\mathrm{u}$ & 39 & $84.6 \%$ & Somatic & g.497C > T & 11,020 & $99.8 \%$ & 1975 & $99.5 \%$ & Germline \\
\hline P_4963a & r. $16302 a>g$ & 708 & $94.7 \%$ & Somatic & g. $16302 A>G$ & 7042 & $97.3 \%$ & 7860 & $86.6 \%$ & Germline \\
\hline
\end{tabular}

Table A2. Variants called at only the mtDNA level.

\begin{tabular}{|c|c|c|c|c|c|c|c|c|c|}
\hline Sample & Variant & Gene & $\begin{array}{c}\text { Depth DNA } \\
\text { Tumor }\end{array}$ & $\begin{array}{c}\text { VAF DNA } \\
\text { Tumor }\end{array}$ & $\begin{array}{l}\text { Depth DNA } \\
\text { Normal }\end{array}$ & $\begin{array}{l}\text { VAF DNA } \\
\text { Normal }\end{array}$ & $\begin{array}{c}\text { Depth RNA } \\
\text { Tumor }\end{array}$ & $\begin{array}{c}\text { VAF RNA } \\
\text { Tumor }\end{array}$ & Concordant? \\
\hline P_6719a & g. $2 \mathrm{~A}>\mathrm{T}$ & Control-Region & 81 & 4.94 & 59 & 0 & 15 & 0.00 & $n a$ \\
\hline P_6409a & g. $66 \mathrm{G}>\mathrm{T}$ & Control-Region & 1712 & 3.27 & 465 & 0 & 644 & 0.16 & $n a$ \\
\hline P_9569a & g.73A $>G$ & Control-Region & 6118 & 11.43 & 146 & 0 & 1010 & 11.58 & Yes \\
\hline P_6719a & g. $185 \mathrm{G}>\mathrm{A}$ & Control-Region & 3193 & 99.72 & 3421 & 99.18 & 10 & 100.00 & Yes \\
\hline P_9592a & g.195T>C & Control-Region & 7012 & 4.04 & 2672 & 0.04 & 1076 & 3.35 & Yes \\
\hline P_4977a & g. $263 A>G$ & Control-Region & 10,036 & 100 & 2142 & 99.91 & 9 & 100.00 & Yes \\
\hline P_9597a & g.293T $>C$ & Control-Region & 2568 & 12.27 & 810 & 0 & 1503 & 7.25 & Yes \\
\hline P_4847a & g. $307 \mathrm{C}>\mathrm{A}$ & Control-Region & 1275 & 22.98 & 2124 & 0.09 & 228 & 0.00 & No \\
\hline P_4958a & g. $316 \mathrm{G}>\mathrm{A}$ & Control-Region & 3513 & 10.65 & 698 & 2.72 & 376 & 3.99 & Yes \\
\hline P_5947a & g.319T $>C$ & Control-Region & 2942 & 4.11 & 1185 & 0.25 & 1015 & 26.21 & Yes \\
\hline P_5947a & g.321T $>C$ & Control-Region & 3184 & 4.74 & 1227 & 0.08 & 1017 & 26.16 & Yes \\
\hline P_4847a & g.346T $>C$ & Control-Region & 1557 & 31.34 & 2300 & 0.04 & 304 & 37.17 & Yes \\
\hline P_4847a & g. $347 \mathrm{G}>\mathrm{A}$ & Control-Region & 1492 & 31.37 & 2030 & 0.05 & 305 & 35.08 & Yes \\
\hline P_11340a & g. $456 C>T$ & Control-Region & 8351 & 99.8 & 462 & 99.78 & 7 & 100.00 & Yes \\
\hline P_9571a & g. $462 C>T$ & Control-Region & 17,653 & 99.93 & 584 & 99.83 & 0 & - & Yes \\
\hline P_6719a & g. $462 C>T$ & Control-Region & 5300 & 99.87 & 5718 & 99.88 & 4 & 100.00 & Yes \\
\hline P_4069a & g. $462 C>T$ & Control-Region & 9108 & 99.89 & 1760 & 100 & 21 & 95.24 & Yes \\
\hline
\end{tabular}


Table A2. Cont.

\begin{tabular}{|c|c|c|c|c|c|c|c|c|c|}
\hline Sample & Variant & Gene & $\begin{array}{c}\text { Depth DNA } \\
\text { Tumor }\end{array}$ & $\begin{array}{c}\text { VAF DNA } \\
\text { Tumor }\end{array}$ & $\begin{array}{c}\text { Depth DNA } \\
\text { Normal }\end{array}$ & $\begin{array}{c}\text { VAF DNA } \\
\text { Normal }\end{array}$ & $\begin{array}{c}\text { Depth RNA } \\
\text { Tumor }\end{array}$ & $\begin{array}{c}\text { VAF RNA } \\
\text { Tumor }\end{array}$ & Concordant \\
\hline P_9571a & g. $489 \mathrm{~T}>\mathrm{C}$ & Control-Region & 18,133 & 99.98 & 619 & 100 & 2 & 100.00 & Yes \\
\hline P_6719a & g.489T $>C$ & Control-Region & 5798 & 99.91 & 5977 & 99.97 & 4 & 100.00 & Yes \\
\hline P_4069a & g. $489 \mathrm{~T}>\mathrm{C}$ & Control-Region & 9408 & 99.97 & 1766 & 100 & 18 & 100.00 & Yes \\
\hline P_6422a & g. $549 C>T$ & Control-Region & 15,224 & 99.76 & 9454 & 99.27 & 15 & 93.33 & Yes \\
\hline P_5928a & g. $730 \mathrm{~A}>\mathrm{T}$ & MT-RNR1 & 12,334 & 12.93 & 395 & 0 & 5056 & 4.94 & Yes \\
\hline P_11389a & g.903T>C & MT-RNR1 & 11,568 & 4.76 & 1006 & 0 & 5053 & 0.26 & Yes \\
\hline P_6413a & g. $1284 \mathrm{~T}>\mathrm{C}$ & MT-RNR1 & 8416 & 25.5 & 2589 & 0.04 & 5030 & 1.83 & Yes \\
\hline P_11399a & g. $1320 \mathrm{G}>\mathrm{A}$ & MT-RNR1 & 6173 & 4.47 & 1995 & 0 & 5039 & 0.02 & $\mathrm{No}^{*}$ \\
\hline P_4845a & g.1464G>A & MT-RNR1 & 6496 & 12.96 & 7902 & 0.19 & 5018 & 6.50 & Yes \\
\hline P_6719a & g. $1748 \mathrm{G}>\mathrm{A}$ & MT-RNR2 & 10,396 & 25.31 & 9000 & 0.06 & 4674 & 10.68 & Yes \\
\hline P_9754a & g. $1758 \mathrm{~T}>\mathrm{C}$ & MT-RNR2 & 10,021 & 3.42 & 2541 & 0.04 & 5035 & 1.81 & Yes \\
\hline P_8618a & g. $1906 \mathrm{G}>\mathrm{C}$ & MT-RNR2 & 8094 & 3.43 & 5953 & 0.03 & 5038 & 0.02 & $\mathrm{No}^{*}$ \\
\hline P_11384a & g.1913G>A & MT-RNR2 & 8494 & 4.07 & 2090 & 0.05 & 5031 & 0.58 & Yes \\
\hline P_9592a & g.1939G >A & MT-RNR2 & 16,324 & 3.59 & 6432 & 0.06 & 5022 & 2.59 & Yes \\
\hline P_6413a & g.1987G >A & MT-RNR2 & 8817 & 11.47 & 2498 & 0.04 & 4972 & 1.57 & Yes \\
\hline P_11380a & g. $2024 \mathrm{C}>\mathrm{T}$ & MT-RNR2 & 12,996 & 14.06 & 647 & 0 & 5024 & 2.31 & Yes \\
\hline P_11377a & g. $2343 \mathrm{G}>\mathrm{A}$ & MT-RNR2 & 7852 & 3.48 & 1118 & 0 & 5049 & 0.04 & $\mathrm{No}^{*}$ \\
\hline P_9572a & g. $2492 \mathrm{G}>\mathrm{A}$ & MT-RNR2 & 13,639 & 3.43 & 671 & 0.15 & 5049 & 5.27 & Yes \\
\hline P_7221a & g.2571G >A & MT-RNR2 & 8410 & 3.22 & 2488 & 0.08 & 5007 & 3.40 & Yes \\
\hline P_11374a & g. $2695 \mathrm{G}>\mathrm{A}$ & MT-RNR2 & 4771 & 3.98 & 1416 & 0 & 5045 & 0.71 & Yes \\
\hline$P_{-} 4976 a$ & g. $2716 \mathrm{G}>\mathrm{A}$ & MT-RNR2 & 21,489 & 7.3 & 18,243 & 0.06 & 4996 & 4.06 & Yes \\
\hline P_5950a & g. $3065 \mathrm{~T}>\mathrm{C}$ & MT-RNR2 & 7371 & 5.24 & 1548 & 0 & 4870 & 3.72 & Yes \\
\hline P_8980a & g.3068G>A & MT-RNR2 & 15,125 & 12.65 & 3374 & 0.12 & 4997 & 4.16 & Yes \\
\hline P_9573a & g. $3097 \mathrm{~T}>\mathrm{C}$ & MT-RNR2 & 10,249 & 9.23 & 592 & 0.17 & 5036 & 5.90 & Yes \\
\hline P_7215a & g. $3617 \mathrm{~T}>\mathrm{C}$ & MT-ND1 & 12,614 & 3.24 & 2196 & 0 & 1400 & 4.07 & Yes \\
\hline P_11375a & g. $3715 G>C$ & MT-ND1 & 9098 & 3.7 & 339 & 0.59 & 4889 & 1.82 & Yes \\
\hline P_4080a & g. $4153 \mathrm{G}>\mathrm{A}$ & MT-ND1 & 14,450 & 7.7 & 2259 & 0.04 & 53 & 3.77 & Yes \\
\hline P_6411a & g. $4308 \mathrm{G}>\mathrm{A}$ & MT-TI & 13,780 & 3.72 & 1097 & 0 & 738 & 6.91 & Yes \\
\hline P_7218a & g. $4336 \mathrm{~T}>\mathrm{C}$ & MT-TQ & 11,432 & 99.9 & 2181 & 100 & 3 & 66.67 & Yes \\
\hline P_8979a & g.4399T >C & MT-TQ & 7338 & 20.37 & 1572 & 0 & 29 & 20.69 & Yes \\
\hline P_4833a & g. $4412 \mathrm{G}>\mathrm{A}$ & MT-TM & 10,532 & 5.86 & 4078 & 0.02 & 1039 & 87.20 & Yes \\
\hline P_4072a & g. $4429 \mathrm{G}>\mathrm{A}$ & MT-TM & 16,360 & 55.94 & 2245 & 0.04 & 548 & 85.22 & Yes \\
\hline P_9777a & g. $4582 \mathrm{~T}>\mathrm{C}$ & MT-ND2 & 3336 & 17.99 & 2439 & 0 & 19 & 0.00 & $n a$ \\
\hline P_11819a & g. $4924 \mathrm{G}>\mathrm{A}$ & MT-ND2 & 7357 & 9.11 & 4036 & 0.05 & 3760 & 6.97 & Yes \\
\hline$P_{-} 4080 a$ & g. $5581 \mathrm{~A}>\mathrm{G}$ & Non-Coding & 17,806 & 99.66 & 2669 & 99.96 & 0 & - & Yes \\
\hline P_6728a & g. $5582 A>G$ & Non-Coding & 13,659 & 99.34 & 11,657 & 99.91 & 9 & 100.00 & Yes \\
\hline
\end{tabular}


Table A2. Cont.

\begin{tabular}{|c|c|c|c|c|c|c|c|c|c|}
\hline Sample & Variant & Gene & $\begin{array}{c}\text { Depth DNA } \\
\text { Tumor }\end{array}$ & $\begin{array}{c}\text { VAF DNA } \\
\text { Tumor }\end{array}$ & $\begin{array}{c}\text { Depth DNA } \\
\text { Normal }\end{array}$ & $\begin{array}{c}\text { VAF DNA } \\
\text { Normal }\end{array}$ & $\begin{array}{c}\text { Depth RNA } \\
\text { Tumor }\end{array}$ & $\begin{array}{c}\text { VAF RNA } \\
\text { Tumor }\end{array}$ & Concordant? \\
\hline P_4982a & g. $5703 \mathrm{G}>\mathrm{A}$ & MT-TN & 13,401 & 91.4 & 2276 & 0.04 & 1963 & 89.61 & Yes \\
\hline P_4971a & g.5920G >A & MT-CO1 & 6202 & 3.58 & 1517 & 0.07 & 4376 & 7.24 & Yes \\
\hline P_11340a & g. $6255 \mathrm{G}>\mathrm{A}$ & MT-CO1 & 11,906 & 6.16 & 824 & 0 & 1638 & 9.77 & Yes \\
\hline P_6422a & g. $6673 \mathrm{~T}>\mathrm{C}$ & MT-CO1 & 20,090 & 4.39 & 12,278 & 0.02 & 1080 & 5.28 & Yes \\
\hline P_9574a & g. $6724 \mathrm{~T}>\mathrm{C}$ & MT-CO1 & 10,549 & 6.03 & 871 & 0 & 5018 & 6.10 & Yes \\
\hline P_9574a & g.7191T>C & MT-CO1 & 11,204 & 6.12 & 932 & 0.11 & 5024 & 5.77 & Yes \\
\hline P_11377a & g.7207G >A & MT-CO1 & 8421 & 5.85 & 1093 & 0 & 5036 & 2.76 & Yes \\
\hline P_7214a & g.7219G >A & MT-CO1 & 11,168 & 3.36 & 2565 & 0 & 4983 & 3.45 & Yes \\
\hline P_4080a & g.7595G >A & MT-CO2 & 17,880 & 20.37 & 2789 & 0.07 & 3 & 0.00 & na \\
\hline P_7219a & g. $7652 \mathrm{~T}>\mathrm{C}$ & MT-CO2 & 9000 & 7.7 & 2654 & 0.04 & 4787 & 7.65 & Yes \\
\hline P_11336a & g.7935T>C & MT-CO2 & 9586 & 5.42 & 594 & 0.34 & 4985 & 7.36 & Yes \\
\hline P_9592a & g. $8213 \mathrm{G}>\mathrm{A}$ & MT-CO2 & 15,889 & 3.63 & 6009 & 0.02 & 4964 & 3.28 & Yes \\
\hline P_4967a & g. $8249 \mathrm{G}>\mathrm{A}$ & MT-CO2 & 13,941 & 3.21 & 7740 & 0.03 & 5031 & 0.85 & Yes \\
\hline P_9572a & g. $8269 \mathrm{G}>\mathrm{C}$ & MT-CO2 & 6539 & 3.17 & 404 & 1.24 & 4858 & 0.00 & No \\
\hline P_11372a & g. $8270 \mathrm{C}>\mathrm{T}$ & Non-Coding & 1447 & 98.48 & 184 & 96.2 & 4755 & 99.75 & Yes \\
\hline P_9002a & g. $8278 C>G$ & Non-Coding & 2694 & 15.55 & 75 & 6.67 & 3092 & 0.00 & No \\
\hline P_9572a & g. $8290 G>C$ & Non-Coding & 6059 & 5.73 & 370 & 2.43 & 96 & 1.04 & na \\
\hline P_9572a & g. $8291 \mathrm{~A}>\mathrm{C}$ & Non-Coding & 6217 & 4.68 & 382 & 2.36 & 93 & 5.38 & Yes \\
\hline P_3989a & g. $8448 \mathrm{~T}>\mathrm{C}$ & MT-ATP8 & 11,980 & 8.68 & 5300 & 0.02 & 5042 & 1.23 & Yes \\
\hline P_7214a & g. $8547 \mathrm{~T}>\mathrm{C}$ & MT-ATP8/6 & 7924 & 3.14 & 1835 & 0.05 & 3949 & 0.20 & Yes \\
\hline P_4977a & g. $8860 A>G$ & MT-ATP6 & 13,075 & 99.99 & 3626 & 99.97 & 46 & 97.83 & Yes \\
\hline P_9754a & g. $9053 \mathrm{G}>\mathrm{A}$ & MT-ATP6 & 10,819 & 4.92 & 2532 & 0 & 5011 & 3.47 & Yes \\
\hline P_9001a & g. $9078 \mathrm{~T}>\mathrm{C}$ & MT-ATP6 & 14,729 & 5.89 & 497 & 0.2 & 2045 & 3.03 & Yes \\
\hline P_4958a & g. $9181 \mathrm{~A}>\mathrm{G}$ & MT-ATP6 & 9010 & 39.35 & 2221 & 0 & 4870 & 49.96 & Yes \\
\hline P_5936a & g. $9285 \mathrm{~A}>\mathrm{T}$ & MT-CO3 & 6732 & 11.51 & 3408 & 0.03 & 4916 & 6.96 & Yes \\
\hline P_6413a & g. $9286 \mathrm{~T}>\mathrm{C}$ & MT-CO3 & 6771 & 11.79 & 1989 & 0.2 & 4904 & 5.69 & Yes \\
\hline P_11337a & g. $9429 \mathrm{G}>\mathrm{A}$ & MT-CO3 & 16,236 & 3.47 & 404 & 0 & 4975 & 3.50 & Yes \\
\hline P_5960a & g. $9497 \mathrm{~T}>\mathrm{C}$ & MT-CO3 & 10,947 & 3.27 & 2603 & 0 & 4961 & 2.80 & Yes \\
\hline P_11336a & g. $9594 \mathrm{C}>\mathrm{T}$ & MT-CO3 & 10,659 & 5.65 & 623 & 0.16 & 4845 & 5.49 & Yes \\
\hline P_9567a & g. $9645 \mathrm{G}>\mathrm{A}$ & MT-CO3 & 11,647 & 6.36 & 700 & 0.14 & 5021 & 3.94 & Yes \\
\hline P_9847a & g.10177G $>A$ & MT-ND3 & 22,790 & 3.05 & 18,685 & 0.02 & 3403 & 7.35 & Yes \\
\hline P_7426a & g.10463T>C & MT-TR & 9817 & 99.98 & 1300 & 99.92 & 7 & 100.00 & Yes \\
\hline P_9757a & g.10747T >C & MT-ND4L & 6998 & 7.82 & 2229 & 0.04 & 4963 & 10.50 & Yes \\
\hline P_11336a & g. $10838 \mathrm{~A}>\mathrm{G}$ & MT-ND4 & 10,950 & 9.52 & 617 & 0 & 5006 & 5.81 & Yes \\
\hline P_5936a & g.11195G > A & MT-ND4 & 7126 & 8.73 & 3615 & 0.03 & 4923 & 7.39 & Yes \\
\hline
\end{tabular}


Table A2. Cont.

\begin{tabular}{|c|c|c|c|c|c|c|c|c|c|}
\hline Sample & Variant & Gene & $\begin{array}{c}\text { Depth DNA } \\
\text { Tumor }\end{array}$ & $\begin{array}{l}\text { VAF DNA } \\
\text { Tumor }\end{array}$ & $\begin{array}{c}\text { Depth DNA } \\
\text { Normal }\end{array}$ & $\begin{array}{l}\text { VAF DNA } \\
\text { Normal }\end{array}$ & $\begin{array}{c}\text { Depth RNA } \\
\text { Tumor }\end{array}$ & $\begin{array}{l}\text { VAF RNA } \\
\text { Tumor }\end{array}$ & Concordant? \\
\hline P_9582a & g.11477G >A & MT-ND4 & 11,726 & 3.77 & 12,886 & 0.02 & 4963 & 5.00 & Yes \\
\hline P_7206a & g.11825G >A & MT-ND4 & 12,293 & 3.54 & 1094 & 0.09 & 4999 & 5.82 & Yes \\
\hline P_4266a & g.11984T >C & MT-ND4 & 14,006 & 13.17 & 8778 & 0.03 & 4951 & 9.41 & Yes \\
\hline P_9755a & g.12154C $>\mathrm{T}$ & MT-TH & 8116 & 3.7 & 1603 & 0.06 & 263 & 8.75 & Yes \\
\hline P_7221a & g.12618G >A & MT-ND5 & 9056 & 6.1 & 2555 & 0.04 & 2853 & 8.24 & Yes \\
\hline P_8981a & g.12769G $>$ A & MT-ND5 & 10,621 & 7.06 & 3108 & 0.03 & 4976 & 8.16 & Yes \\
\hline P_5930a & g.12771G $>A$ & MT-ND5 & 10,265 & 11.83 & 3150 & 0 & 4972 & 9.61 & Yes \\
\hline P_6413a & g.12977T >C & MT-ND5 & 7340 & 34.1 & 2123 & 0.09 & 4942 & 2.47 & Yes \\
\hline P_4847a & g.13099G >A & MT-ND5 & 13,805 & 5.16 & 4972 & 0.02 & 4931 & 1.60 & Yes \\
\hline P_7409a & g.13156C > T & MT-ND5 & 8790 & 4.55 & 2599 & 0.04 & 4891 & 7.56 & Yes \\
\hline P_5946a & g.13178G > A & MT-ND5 & 5740 & 8.89 & 2846 & 0.07 & 3483 & 11.08 & Yes \\
\hline P_8979a & g.13198G >A & MT-ND5 & 11,789 & 8.59 & 2741 & 0 & 2877 & 7.92 & Yes \\
\hline P_11336a & g. $13272 C>A$ & MT-ND5 & 9660 & 5.48 & 579 & 0 & 4603 & 2.00 & Yes \\
\hline P_8979a & g.13496C >A & MT-ND5 & 10,985 & 5.5 & 2332 & 0.04 & 3916 & 5.80 & Yes \\
\hline P_11374a & g.13531G >A & MT-ND5 & 4731 & 5.14 & 1252 & 0 & 5007 & 3.87 & Yes \\
\hline P_11391a & g.13567A>G & MT-ND5 & 1322 & 23.83 & 856 & 0 & 5009 & 0.86 & Yes \\
\hline P_11372a & g.14112C >A & MT-ND5 & 8553 & 10.1 & 1251 & 0.08 & 4959 & 10.71 & Yes \\
\hline P_8611a & g.14197T>C & MT-ND6 & 10,577 & 5.01 & 4713 & 0.04 & 5005 & 5.97 & Yes \\
\hline P_7215a & g.14447T>C & MT-ND6 & 13,776 & 3.47 & 2242 & 0 & 2321 & 2.76 & Yes \\
\hline P_11374a & g.14760G $>A$ & MT-CYB & 5961 & 19.28 & 1421 & 0.07 & 921 & 0.00 & No \\
\hline P_4959a & g. $14788 \mathrm{~T}>\mathrm{C}$ & MT-CYB & 13,250 & 10.17 & 8208 & 0.12 & 4608 & 6.45 & Yes \\
\hline P_9570a & g.14888G >A & MT-CYB & 15,466 & 3.84 & 517 & 0 & 3649 & 5.10 & Yes \\
\hline P_5954a & g. $14939 \mathrm{~T}>\mathrm{C}$ & MT-CYB & 8033 & 3.39 & 2633 & 0.04 & 2959 & 6.69 & Yes \\
\hline P_4982a & g. $15012 \mathrm{~T}>\mathrm{C}$ & MT-CYB & 22,666 & 8.39 & 4348 & 0.05 & 5016 & 7.93 & Yes \\
\hline P_5950a & g.15093G > A & MT-CYB & 8082 & 5.26 & 1601 & 0 & 5037 & 7.72 & Yes \\
\hline P_9582a & g.15170G >A & MT-CYB & 11,759 & 3.46 & 13,082 & 0.02 & 3899 & 9.69 & Yes \\
\hline P_11342a & g.15242G $>$ A & MT-CYB & 11,745 & 3.32 & 373 & 0 & 4339 & 6.04 & Yes \\
\hline P_9582a & g.15854T >C & MT-CYB & 10,545 & 6.89 & 12,711 & 0.06 & 3895 & 7.01 & Yes \\
\hline P_4977a & g.15970T>C & MT-TP & 19,783 & 99.96 & 5232 & 100 & 3 & 100.00 & Yes \\
\hline P_4847a & g.16033G >A & Control-Region & 14,332 & 7.59 & 5556 & 0.02 & 2732 & 0.48 & Yes \\
\hline P_7433a & g. $16147 \mathrm{C}>\mathrm{T}$ & Control-Region & 15,174 & 11 & 3874 & 0.03 & 2873 & 1.98 & Yes \\
\hline P_9539a & g.16293A>G & Control-Region & 2683 & 9.58 & 470 & 0.21 & 3315 & 9.20 & Yes \\
\hline
\end{tabular}


Table A3. Variants at only the mtRNA level.

\begin{tabular}{|c|c|c|c|c|c|c|}
\hline Sample & Variant & Gene & Class & Depth RNA Tumor & VAF RNA Tumor & Comment \\
\hline P_4982a & $\mathrm{r} .72 \mathrm{u}>\mathrm{c}$ & Control-Region & Somatic & 318 & 20.44 & True variant (mutually exclusive 73G, 94T) \\
\hline P_6406a & $\mathrm{r} .72 \mathrm{u}>\mathrm{c}$ & Control-Region & Germline & 1906 & 99.79 & True variant \\
\hline P_9589a & r.73a $>$ g & Control-Region & Germline & 592 & 99.83 & True variant \\
\hline P_5959a & r.73a $>\mathrm{g}$ & Control-Region & Germline & 954 & 100.00 & True variant \\
\hline P_11394a & r.73a $>\mathrm{g}$ & Control-Region & Germline & 923 & 100.00 & True variant \\
\hline P_11389a & r.146u>c & Control-Region & Germline & 694 & 99.71 & True variant \\
\hline P_8978a & r.146u >c & Control-Region & Germline & 371 & 99.73 & True variant (phased with $185 \mathrm{~A}$ and $204 \mathrm{C}$ ) \\
\hline P_8611a & r.146u >c & Control-Region & Germline & 1599 & 99.75 & True variant (phased with 195C) \\
\hline P_8981a & r. $146 \mathrm{u}>\mathrm{c}$ & Control-Region & Germline & 308 & 100.00 & True variant \\
\hline P_8609a & r. $152 u>c$ & Control-Region & Somatic & 1448 & 69.96 & True variant (phased with 195C) \\
\hline P_10014a & r. $152 u>c$ & Control-Region & Germline & 2272 & 95.38 & True variant \\
\hline P_4606a & r. $152 u>c$ & Control-Region & Germline & 98 & 98.98 & True variant \\
\hline P_4266a & r. $152 u>c$ & Control-Region & Germline & 956 & 99.37 & True variant \\
\hline P_8618a & r. $152 u>c$ & Control-Region & Germline & 437 & 99.77 & True variant \\
\hline P_8979a & r. $152 u>c$ & Control-Region & Germline & 371 & 100.00 & True variant \\
\hline P_4261a & $\mathrm{r} .182 \mathrm{c}>\mathrm{u}$ & Control-Region & Somatic & 1220 & 77.54 & True variant \\
\hline P_11383a & r. $185 \mathrm{~g}>\mathrm{a}$ & Control-Region & Germline & 301 & 99.67 & True variant (phased with 150T and 228A) \\
\hline P_5928a & $\mathrm{r} .185 \mathrm{~g}>\mathrm{a}$ & Control-Region & Germline & 723 & 100.00 & True variant (phased with $188 \mathrm{G}$ and $228 \mathrm{~A}$ ) \\
\hline P_9592a & r.188a $>$ g & Control-Region & Germline & 814 & 99.63 & True variant (phased with $185 \mathrm{~A}$ and $228 \mathrm{~A})$ \\
\hline P_5928a & r.188a $>\mathrm{g}$ & Control-Region & Germline & 716 & 100.00 & True variant (phased with $185 \mathrm{~A}$ and $228 \mathrm{~A}$ ) \\
\hline P_5956a & $\mathrm{r} .188 \mathrm{a}>\mathrm{g}$ & Control-Region & Germline & 1450 & 100.00 & True variant (phased with 185A and 228A) \\
\hline P_9571a & r.188a $>$ g & Control-Region & Germline & 37 & 100.00 & True variant (phased with $185 \mathrm{~A}, 222 \mathrm{~T}$ and $228 \mathrm{~A}$ ) \\
\hline P_4069a & r.189a $>\mathrm{g}$ & Control-Region & Germline & 997 & 100.00 & True variant \\
\hline P_11372a & r.195u>c & Control-Region & Germline & 715 & 99.72 & True variant (phased with 152C and 263G) \\
\hline P_8978a & $\mathrm{r} .228 \mathrm{~g}>\mathrm{a}$ & Control-Region & Somatic & 573 & 82.72 & True variant (phased with 185A, 204C, 263G) \\
\hline P_11383a & $\mathrm{r} .228 \mathrm{~g}>\mathrm{a}$ & Control-Region & Germline & 585 & 99.83 & True variant (phased with 185A, 263G, 295T) \\
\hline P_9597a & r.263a>g & Control-Region & Germline & 2341 & 99.83 & True variant (phased with 228A and 295T) \\
\hline P_10010a & r.263a>g & Control-Region & Germline & 1331 & 99.85 & True variant \\
\hline P_7238a & r.263a $>\mathrm{g}$ & Control-Region & Germline & 1388 & 99.86 & True variant (phased with 295T) \\
\hline P_8611a & r.263a>g & Control-Region & Germline & 1948 & 99.95 & True variant (phased with 195C) \\
\hline P_8830a & r.263a>g & Control-Region & Germline & 892 & 100.00 & True variant (phased with 207A and 234G) \\
\hline P_7238a & r. $295 c>0$ & Control-Region & Germline & 766 & 99.48 & True variant (phased with 263G) \\
\hline P_5956a & $\mathrm{r} .295 \mathrm{c}>\mathrm{u}$ & Control-Region & Germline & 1121 & 99.91 & True variant (phased with 263G) \\
\hline P_6732a & $\mathrm{r} .295 \mathrm{c}>\mathrm{u}$ & Control-Region & Germline & 545 & 100.00 & True variant \\
\hline P_9597a & r. $295 c>u$ & Control-Region & Germline & 1272 & 100.00 & True variant (phased with 228A and 263G) \\
\hline P_7316a & $\mathrm{r} .456 \mathrm{c}>\mathrm{u}$ & Control-Region & Germline & 88 & 95.45 & True variant \\
\hline P_9758a & r.1604g>a & MT-TV & Somatic & 159 & 23.27 & True variant \\
\hline P_11399a & $\mathrm{r} .1669 \mathrm{~g}>\mathrm{a}$ & MT-TV & Somatic & 534 & 41.20 & True variant \\
\hline P_6730a & r.1973g>a & MT-RNR2 & Somatic & 1171 & 57.05 & True variant \\
\hline P_4977a & r.2166c $>\mathrm{u}$ & MT-RNR2 & Somatic & 1433 & 18.42 & Potential artefact; at start of read ACCXATA context \\
\hline
\end{tabular}


Table A3. Cont.

\begin{tabular}{|c|c|c|c|c|c|c|}
\hline Sample & Variant & Gene & Class & Depth RNA Tumor & VAF RNA Tumor & Comment \\
\hline P_10010a & $\mathrm{r} .2300 \mathrm{~g}>\mathrm{a}$ & MT-RNR2 & Somatic & 2066 & 13.84 & True variant (in DNA! 2300G>A, $9106|5497| 37.64 \%$ ) \\
\hline P_7431a & r.2416u>c & MT-RNR2 & Somatic & 855 & 84.80 & True variant \\
\hline P_6406a & r. $3109 u>c$ & MT-RNR2 & Somatic & 1407 & 38.38 & True variant \\
\hline P_4963a & r.3283g>a & MT-TL1 & Somatic & 908 & 29.52 & True variant \\
\hline P_4606a & r. $3535 u>c$ & MT-ND1 & Somatic & 2203 & 92.74 & True variant \\
\hline P_4080a & $\mathrm{r} .3705 \mathrm{~g}>\mathrm{a}$ & MT-ND1 & Somatic & 51 & 94.12 & True variant \\
\hline P_5942a & r.3796a>g & MT-ND1 & Germline & 2032 & 98.43 & True variant \\
\hline P_9754a & r.3913g>a & MT-ND1 & Somatic & 1685 & 12.11 & True variant \\
\hline P_7219a & $\mathrm{r} .4282 \mathrm{~g}>\mathrm{a}$ & MT-TI & Somatic & 76 & 35.53 & True variant \\
\hline P_6733a & $\mathrm{r} .4360 \mathrm{~g}>\mathrm{a}$ & MT-TQ & Somatic & 54 & 40.74 & True variant \\
\hline P_6728a & $\mathrm{r} .4408 \mathrm{~g}>\mathrm{a}$ & MT-TM & Somatic & 199 & 17.09 & True variant \\
\hline P_6043a & r.4986a>g & MT-ND2 & Somatic & 2073 & 39.22 & True variant \\
\hline P_4847a & r. $5479 u>c$ & MT-ND2 & Somatic & 890 & 13.03 & Potential artefact; at end of read TCCXACC context \\
\hline P_9567a & r. $6569 \mathrm{c}>\mathrm{u}$ & MT-CO1 & Somatic & 1773 & 88.72 & True variant \\
\hline P_4970a & r.7045u>c & MT-CO1 & Somatic & 761 & 12.22 & True variant \\
\hline P_9847a & r.7146a>g & MT-CO1 & Germline & 757 & 98.15 & True variant \\
\hline P_9757a & r. $7579 u>c$ & MT-TD & Somatic & 109 & 16.51 & True variant \\
\hline P_11383a & r.7698u>c & MT-CO2 & Somatic & 2277 & 12.60 & True variant \\
\hline P_9541a & r.7765a>g & MT-CO2 & Somatic & 797 & 17.69 & True variant \\
\hline P_4976a & r.7895u>c & MT-CO2 & Somatic & 2368 & 28.08 & True variant \\
\hline P_11819a & r. $8149 \mathrm{a}>\mathrm{g}$ & MT-CO2 & Somatic & 660 & 92.58 & True variant \\
\hline P_7216a & r. $8286 u>c$ & Non-Coding & Somatic & 364 & 49.73 & True variant \\
\hline P_8978a & $\mathrm{r} .8408 \mathrm{c}>\mathrm{u}$ & MT-ATP8 & Germline & 2239 & 99.60 & True variant \\
\hline P_4604a & r. $9989 u>c$ & MT-CO3 & Germline & 302 & 98.68 & True variant \\
\hline P_4833a & r.10306a>c & MT-ND3 & Somatic & 1004 & 35.26 & True variant \\
\hline P_4976a & r.11718g $>a$ & MT-ND4 & Somatic & 1304 & 92.33 & True variant \\
\hline P_6722a & r. $11899 \mathrm{u}>\mathrm{c}$ & MT-ND4 & Germline & 691 & 95.37 & True variant (phased with 11914A) \\
\hline P_8978a & r. $12763 \mathrm{~g}>\mathrm{a}$ & MT-ND5 & Somatic & 1602 & 89.20 & True variant \\
\hline P_9754a & r.12876c $>\mathrm{u}$ & MT-ND5 & Germline & 1478 & 97.29 & True variant \\
\hline P_6411a & r.13528a $>\mathrm{g}$ & MT-ND5 & Somatic & 1701 & 91.59 & True variant \\
\hline P_4983a & r. $13552 \mathrm{~g}>\mathrm{a}$ & MT-ND5 & Somatic & 1569 & 91.65 & True variant \\
\hline P_9002a & r.14389c $>\mathrm{u}$ & MT-ND6 & Somatic & 1718 & 93.95 & True variant \\
\hline P_5930a & r.14721g $>\mathrm{c}$ & MT-TE & Somatic & 302 & 27.81 & True variant (phased with 14766T) \\
\hline P_8978a & r.15495u >c & MT-CYB & Somatic & 1812 & 94.09 & True variant \\
\hline P_11337a & r.15607a $>g$ & MT-CYB & Germline & 959 & 99.06 & True variant \\
\hline P_4982a & r. $15904 c>\mathrm{u}$ & MT-TT & Somatic & 344 & 34.01 & True variant (overlapping 15927A) \\
\hline P_4982a & r. $15927 \mathrm{~g}>\mathrm{a}$ & MT-TT & Somatic & 344 & 36.92 & True variant (overlapping with 15904) \\
\hline P_4847a & r.16092u>c & Control-Region & Germline & 1838 & 99.78 & True variant \\
\hline P_11389a & r.16093u>c & Control-Region & Somatic & 745 & 12.62 & True variant \\
\hline P_9582a & r.16093u>c & Control-Region & Somatic & 753 & 12.88 & True variant (phased with $16126 \mathrm{C}$ ) \\
\hline P_4072a & r. $16093 u>c$ & Control-Region & Germline & 1041 & 27.76 & True variant \\
\hline
\end{tabular}


Table A3. Cont.

\begin{tabular}{|c|c|c|c|c|c|c|}
\hline Sample & Variant & Gene & Class & Depth RNA Tumor & VAF RNA Tumor & Comment \\
\hline P_9567a & r.16093u>c & Control-Region & Somatic & 2459 & 92.19 & True variant \\
\hline P_4955a & r. $16093 u>c$ & Control-Region & Germline & 1298 & 98.69 & True variant \\
\hline P_4970a & r. $16104 c>u$ & Control-Region & Germline & 800 & 81.88 & True variant \\
\hline P_8979a & r.16184c $>\mathrm{u}$ & Control-Region & Germline & 317 & 100.00 & True variant \\
\hline P_4606a & r.16186c $>$ u & Control-Region & Germline & 181 & 96.69 & True variant \\
\hline P_8830a & r. $16209 u>c$ & Control-Region & Germline & 863 & 100.00 & True variant (phased with $16171 \mathrm{~A}, 16183 \mathrm{C}, 16188 \mathrm{C}, 16233 \mathrm{~T}, 16258 \mathrm{~T}$ ) \\
\hline P_8830a & r. $16223 \mathrm{c}>\mathrm{u}$ & Control-Region & Germline & 1197 & 100.00 & True variant (phased with $16171 \mathrm{~A}, 16183 \mathrm{C}, 16188 \mathrm{C}, 1609 \mathrm{C}, 16258 \mathrm{~T}$ ) \\
\hline P_9002a & r.16235a>g & Control-Region & Germline & 1409 & 82.82 & True variant (phased with 16183C, 16184A, 16189C, 16217C) \\
\hline P_11338a & r.16235a>g & Control-Region & Somatic & 2188 & 93.01 & True variant (phased with $16293 \mathrm{G}$ and $16304 \mathrm{C}$ ) \\
\hline P_6730a & r.16267c $>\mathrm{u}$ & Control-Region & Somatic & 2167 & 34.98 & True variant \\
\hline P_6732a & r. $16278 c>u$ & Control-Region & Somatic & 2661 & 47.35 & True variant \\
\hline P_9575a & r.16290c $>\mathrm{u}$ & Control-Region & Somatic & 1530 & 25.16 & True variant (phased with 16265C, 16291T, 16335G) \\
\hline P_11341a & r.16293a>g & Control-Region & Germline & 1205 & 100.00 & True variant (phased with $16331 \mathrm{C}, 16354 \mathrm{~T}$ ) \\
\hline P_9582a & r. $16294 c>u$ & Control-Region & Germline & 870 & 99.89 & True variant (phased with $16304 \mathrm{C}$ ) \\
\hline P_9847a & r. $16294 c>u$ & Control-Region & Germline & 731 & 100.00 & True variant (phased with 16278T, 16293G, 16311C, 16360T) \\
\hline P_9582a & r. $16304 u>c$ & Control-Region & Germline & 663 & 99.85 & True variant (phased with 16294T) \\
\hline P_9596a & r. $16311 u>c$ & Control-Region & Germline & 802 & 98.63 & True variant \\
\hline P_5956a & r. $16311 \mathrm{u}>\mathrm{c}$ & Control-Region & Germline & 757 & 100.00 & True variant \\
\hline P_9761a & r.16336g $>a$ & Control-Region & Germline & 1571 & 100.00 & True variant \\
\hline P_9541a & r. $16342 u>c$ & Control-Region & Germline & 806 & 99.75 & True variant \\
\hline P_11381a & r.16356u >c & Control-Region & Germline & 1466 & 99.86 & True variant \\
\hline P_9568a & r. $16362 u>c$ & Control-Region & Germline & 1232 & 99.84 & True variant (phased with $16304 \mathrm{C}$ ) \\
\hline P_5946a & r. $16362 u>c$ & Control-Region & Germline & 327 & 100.00 & True variant \\
\hline P_9599a & r. $16362 u>c$ & Control-Region & Germline & 376 & 100.00 & True variant (phased with $16325 \mathrm{C}$ ) \\
\hline P_11819a & r. $16362 u>c$ & Control-Region & Germline & 373 & 100.00 & True variant \\
\hline P_10010a & r. $16519 u>c$ & Control-Region & Somatic & 732 & 56.15 & True variant \\
\hline P_6730a & r.16540c $>\mathrm{u}$ & Control-Region & Somatic & 1142 & 61.56 & True variant (phased with 16519C) \\
\hline
\end{tabular}




\section{References}

1. Ojala, D.; Montoya, J.; Attardi, G. tRNA punctuation model of RNA processing in human mitochondria. Nature 1981, 290, 470-474. [CrossRef] [PubMed]

2. Reznik, E.; Miller, M.L.; Senbabaoglu, Y.; Riaz, N.; Sarungbam, J.; Tickoo, S.K.; Al-Ahmadie, H.A.; Lee, W.; Seshan, V.E.; Hakimi, A.A.; et al. Mitochondrial DNA copy number variation across human cancers. Elife 2016, 5. [CrossRef]

3. Mambo, E.; Chatterjee, A.; Xing, M.; Tallini, G.; Haugen, B.R.; Yeung, S.C.; Sukumar, S.; Sidransky, D. Tumor-specific changes in mtDNA content in human cancer. Int. J. Cancer 2005, 116, 920-924. [CrossRef] [PubMed]

4. Yu, M.; Zhou, Y.; Shi, Y.; Ning, L.; Yang, Y.; Wei, X.; Zhang, N.; Hao, X.; Niu, R. Reduced mitochondrial DNA copy number is correlated with tumor progression and prognosis in Chinese breast cancer patients. IUBMB Life 2007, 59, 450-457. [CrossRef] [PubMed]

5. Tseng, L.M.; Yin, P.H.; Chi, C.W.; Hsu, C.Y.; Wu, C.W.; Lee, L.M.; Wei, Y.H.; Lee, H.C. Mitochondrial DNA mutations and mitochondrial DNA depletion in breast cancer. Genes Chromosomes Cancer 2006, 45, 629-638. [CrossRef]

6. Fan, A.X.; Radpour, R.; Haghighi, M.M.; Kohler, C.; Xia, P.; Hahn, S.; Holzgreve, W.; Zhong, X.Y. Mitochondrial DNA content in paired normal and cancerous breast tissue samples from patients with breast cancer. J. Cancer Res. Clin. Oncol. 2009, 135, 983-989. [CrossRef]

7. Barekati, Z.; Radpour, R.; Kohler, C.; Zhang, B.; Toniolo, P.; Lenner, P.; Lv, Q.; Zheng, H.; Zhong, X.Y. Methylation profile of TP53 regulatory pathway and mtDNA alterations in breast cancer patients lacking TP53 mutations. Hum. Mol. Genet. 2010, 19, 2936-2946. [CrossRef]

8. McMahon, S.; LaFramboise, T. Mutational patterns in the breast cancer mitochondrial genome, with clinical correlates. Carcinogenesis 2014, 35, 1046-1054. [CrossRef] [PubMed]

9. Bai, R.K.; Chang, J.; Yeh, K.T.; Lou, M.A.; Lu, J.F.; Tan, D.J.; Liu, H.; Wong, L.J. Mitochondrial DNA content varies with pathological characteristics of breast cancer. J. Oncol. 2011, 2011, 496189. [CrossRef] [PubMed]

10. Hsu, C.W.; Yin, P.H.; Lee, H.C.; Chi, C.W.; Tseng, L.M. Mitochondrial DNA content as a potential marker to predict response to anthracycline in breast cancer patients. Breast J. 2010, 16, 264-270. [CrossRef]

11. Reznik, E.; Wang, Q.G.; La, K.; Schultz, N.; Sander, C. Mitochondrial respiratory gene expression is suppressed in many cancers. Elife 2017, 6. [CrossRef] [PubMed]

12. Warburg, O. On the origin of cancer cells. Science 1956, 123, 309-314. [CrossRef] [PubMed]

13. Weerts, M.J.; Sieuwerts, A.M.; Smid, M.; Look, M.P.; Foekens, J.A.; Sleijfer, S.; Martens, J.W. Mitochondrial DNA content in breast cancer: Impact on in vitro and in vivo phenotype and patient prognosis. Oncotarget 2016, 7, 29166-29176. [CrossRef] [PubMed]

14. Weerts, M.J.A.; Hollestelle, A.; Sieuwerts, A.M.; Foekens, J.A.; Sleijfer, S.; Martens, J.W.M. Low tumor mitochondrial DNA content is associated with better outcome in breast cancer patients receiving anthracycline-based chemotherapy. Clin. Cancer Res. 2017, 23, 4735-4743. [CrossRef] [PubMed]

15. Ju, Y.S.; Alexandrov, L.B.; Gerstung, M.; Martincorena, I.; Nik-Zainal, S.; Ramakrishna, M.; Davies, H.R.; Papaemmanuil, E.; Gundem, G.; Shlien, A.; et al. Origins and functional consequences of somatic mitochondrial DNA mutations in human cancer. Elife 2014, 3. [CrossRef] [PubMed]

16. Stewart, J.B.; Alaei-Mahabadi, B.; Sabarinathan, R.; Samuelsson, T.; Gorodkin, J.; Gustafsson, C.M.; Larsson, E. Simultaneous DNA and RNA mapping of somatic mitochondrial mutations across diverse human cancers. PLoS Genet. 2015, 11, e1005333. [CrossRef] [PubMed]

17. Nik-Zainal, S.; Davies, H.; Staaf, J.; Ramakrishna, M.; Glodzik, D.; Zou, X.; Martincorena, I.; Alexandrov, L.B.; Martin, S.; Wedge, D.C.; et al. Landscape of somatic mutations in 560 breast cancer whole-genome sequences. Nature 2016, 534, 47-54. [CrossRef]

18. Bar-Yaacov, D.; Avital, G.; Levin, L.; Richards, A.L.; Hachen, N.; Rebolledo Jaramillo, B.; Nekrutenko, A.; Zarivach, R.; Mishmar, D. RNA-DNA differences in human mitochondria restore ancestral form of $16 \mathrm{~S}$ ribosomal RNA. Genome Res. 2013, 23, 1789-1796. [CrossRef]

19. Hodgkinson, A.; Idaghdour, Y.; Gbeha, E.; Grenier, J.C.; Hip-Ki, E.; Bruat, V.; Goulet, J.P.; de Malliard, T.; Awadalla, P. High-resolution genomic analysis of human mitochondrial RNA sequence variation. Science 2014, 344, 413-415. [CrossRef] 
20. Nielsen, M.M.; Tehler, D.; Vang, S.; Sudzina, F.; Hedegaard, J.; Nordentoft, I.; Orntoft, T.F.; Lund, A.H.; Pedersen, J.S. Identification of expressed and conserved human noncoding RNAs. RNA 2014, 20, $236-251$. [CrossRef]

21. Grandhi, S.; Bosworth, C.; Maddox, W.; Sensiba, C.; Akhavanfard, S.; Ni, Y.; LaFramboise, T. Heteroplasmic shifts in tumor mitochondrial genomes reveal tissue-specific signals of relaxed and positive selection. Hum. Mol. Genet. 2017, 3798753. [CrossRef] [PubMed]

22. Mercer, T.R.; Neph, S.; Dinger, M.E.; Crawford, J.; Smith, M.A.; Shearwood, A.M.; Haugen, E.; Bracken, C.P.; Rackham, O.; Stamatoyannopoulos, J.A.; et al. The human mitochondrial transcriptome. Cell 2011, 146, 645-658. [CrossRef] [PubMed]

23. Mele, M.; Ferreira, P.G.; Reverter, F.; DeLuca, D.S.; Monlong, J.; Sammeth, M.; Young, T.R.; Goldmann, J.M.; Pervouchine, D.D.; Sullivan, T.J.; et al. Human genomics. The human transcriptome across tissues and individuals. Science 2015, 348, 660-665. [CrossRef] [PubMed]

24. Jia, D.; Park, J.H.; Jung, K.H.; Levine, H.; Kaipparettu, B.A. Elucidating the Metabolic Plasticity of Cancer: Mitochondrial Reprogramming and Hybrid Metabolic States. Cells 2018, 7. [CrossRef] [PubMed]

25. Chen, J.Q.; Delannoy, M.; Cooke, C.; Yager, J.D. Mitochondrial localization of ERalpha and ERbeta in human MCF7 cells. Am. J. Physiol. Endocrinol. Metab. 2004, 286, E1011-E1022. [CrossRef] [PubMed]

26. Mattingly, K.A.; Ivanova, M.M.; Riggs, K.A.; Wickramasinghe, N.S.; Barch, M.J.; Klinge, C.M. Estradiol stimulates transcription of nuclear respiratory factor-1 and increases mitochondrial biogenesis. Mol. Endocrinol. 2008, 22, 609-622. [CrossRef] [PubMed]

27. Pelicano, H.; Zhang, W.; Liu, J.; Hammoudi, N.; Dai, J.; Xu, R.H.; Pusztai, L.; Huang, P. Mitochondrial dysfunction in some triple-negative breast cancer cell lines: Role of mTOR pathway and therapeutic potential. Breast Cancer Res. 2014, 16, 434. [CrossRef] [PubMed]

28. Wang, C.L.; MacDonald, L.R.; Rogers, J.V.; Aravkin, A.; Haseley, D.R.; Beatty, J.D. Positron emission mammography: Correlation of estrogen receptor, progesterone receptor, and human epidermal growth factor receptor 2 status and 18F-FDG. AJR Am. J. Roentgenol. 2011, 197, W247-W255. [CrossRef]

29. Yoon, H.J.; Kang, K.W.; Chun, I.K.; Cho, N.; Im, S.A.; Jeong, S.; Lee, S.; Jung, K.C.; Lee, Y.S.; Jeong, J.M.; et al. Correlation of breast cancer subtypes, based on estrogen receptor, progesterone receptor, and HER2, with functional imaging parameters from (6)(8)Ga-RGD PET/CT and (1)(8)F-FDG PET/CT. Eur. J. Nucl. Med. Mol. Imaging 2014, 41, 1534-1543. [CrossRef]

30. Gil-Rendo, A.; Martinez-Regueira, F.; Zornoza, G.; Garcia-Velloso, M.J.; Beorlegui, C.; Rodriguez-Spiteri, N. Association between [18F]fluorodeoxyglucose uptake and prognostic parameters in breast cancer. Br. J. Surg. 2009, 96, 166-170. [CrossRef]

31. Ikenaga, N.; Otomo, N.; Toyofuku, A.; Ueda, Y.; Toyoda, K.; Hayashi, T.; Nishikawa, K.; Tanaka, M. Standardized uptake values for breast carcinomas assessed by fluorodeoxyglucose-positron emission tomography correlate with prognostic factors. Am. Surg. 2007, 73, 1151-1157. [PubMed]

32. Mavi, A.; Cermik, T.F.; Urhan, M.; Puskulcu, H.; Basu, S.; Yu, J.Q.; Zhuang, H.; Czerniecki, B.; Alavi, A. The effects of estrogen, progesterone, and C-erbB-2 receptor states on 18F-FDG uptake of primary breast cancer lesions. J. Nucl. Med. 2007, 48, 1266-1272. [CrossRef] [PubMed]

33. Nakajo, M.; Kajiya, Y.; Kaneko, T.; Kaneko, Y.; Takasaki, T.; Tani, A.; Ueno, M.; Koriyama, C.; Nakajo, M. FDG PET/CT and diffusion-weighted imaging for breast cancer: Prognostic value of maximum standardized uptake values and apparent diffusion coefficient values of the primary lesion. Eur. J. Nucl. Med. Mol. Imaging 2010, 37, 2011-2020. [CrossRef] [PubMed]

34. Osborne, J.R.; Port, E.; Gonen, M.; Doane, A.; Yeung, H.; Gerald, W.; Cook, J.B.; Larson, S. 18F-FDG PET of locally invasive breast cancer and association of estrogen receptor status with standardized uptake value: Microarray and immunohistochemical analysis. J. Nucl. Med. 2010, 51, 543-550. [CrossRef] [PubMed]

35. Tseng, L.M.; Yin, P.H.; Yang, C.W.; Tsai, Y.F.; Hsu, C.Y.; Chi, C.W.; Lee, H.C. Somatic mutations of the mitochondrial genome in human breast cancers. Genes Chromosomes Cancer 2011, 50, 800-811. [CrossRef] [PubMed]

36. Tan, D.J.; Bai, R.K.; Wong, L.J. Comprehensive scanning of somatic mitochondrial DNA mutations in breast cancer. Cancer Res. 2002, 62, 972-976. [PubMed]

37. Coller, H.A.; Khrapko, K.; Bodyak, N.D.; Nekhaeva, E.; Herrero-Jimenez, P.; Thilly, W.G. High frequency of homoplasmic mitochondrial DNA mutations in human tumors can be explained without selection. Nat. Genet. 2001, 28, 147-150. [CrossRef] 
38. Samuels, D.C.; Li, C.; Li, B.; Song, Z.; Torstenson, E.; Boyd Clay, H.; Rokas, A.; Thornton-Wells, T.A.; Moore, J.H.; Hughes, T.M.; et al. Recurrent tissue-specific mtDNA mutations are common in humans. PLoS Genet. 2013, 9, e1003929. [CrossRef]

39. He, Y.; Wu, J.; Dressman, D.C.; Iacobuzio-Donahue, C.; Markowitz, S.D.; Velculescu, V.E.; Diaz, L.A., Jr.; Kinzler, K.W.; Vogelstein, B.; Papadopoulos, N. Heteroplasmic mitochondrial DNA mutations in normal and tumour cells. Nature 2010, 464, 610-614. [CrossRef]

40. Li, M.K.; Schroder, R.; Ni, S.Y.; Madea, B.; Stoneking, M. Extensive tissue-related and allele-related mtDNA heteroplasmy suggests positive selection for somatic mutations. Proc. Natl. Acad. Sci. USA 2015, 112, 2491-2496. [CrossRef]

41. Calloway, C.D.; Reynolds, R.L.; Herrin, G.L., Jr.; Anderson, W.W. The frequency of heteroplasmy in the HVII region of mtDNA differs across tissue types and increases with age. Am. J. Hum. Genet. 2000, 66, 1384-1397. [CrossRef] [PubMed]

42. Johnson, A.A.; Johnson, K.A. Exonuclease proofreading by human mitochondrial DNA polymerase. J. Biol. Chem. 2001, 276, 38097-38107. [CrossRef] [PubMed]

43. Collura, R.V.; Auerbach, M.R.; Stewart, C.B. A quick, direct method that can differentiate expressed mitochondrial genes from their nuclear pseudogenes. Curr. Biol. 1996, 6, 1337-1339. [CrossRef]

44. Ramos, A.; Barbena, E.; Mateiu, L.; del Mar Gonzalez, M.; Mairal, Q.; Lima, M.; Montiel, R.; Aluja, M.P.; Santos, C. Nuclear insertions of mitochondrial origin: Database updating and usefulness in cancer studies. Mitochondrion 2011, 11, 946-953. [CrossRef] [PubMed]

45. Parr, R.L.; Maki, J.; Reguly, B.; Dakubo, G.D.; Aguirre, A.; Wittock, R.; Robinson, K.; Jakupciak, J.P.; Thayer, R.E. The pseudo-mitochondrial genome influences mistakes in heteroplasmy interpretation. BMC Genomics 2006, 7, 185. [CrossRef] [PubMed]

46. Parfait, B.; Rustin, P.; Munnich, A.; Rotig, A. Co-amplification of nuclear pseudogenes and assessment of heteroplasmy of mitochondrial DNA mutations. Biochem. Biophys. Res. Commun. 1998, 247, 57-59. [CrossRef]

47. Albayrak, L.; Khanipov, K.; Pimenova, M.; Golovko, G.; Rojas, M.; Pavlidis, I.; Chumakov, S.; Aguilar, G.; Chavez, A.; Widger, W.R.; et al. The ability of human nuclear DNA to cause false positive low-abundance heteroplasmy calls varies across the mitochondrial genome. BMC Genomics 2016, 17, 1017. [CrossRef]

48. Hazkani-Covo, E.; Zeller, R.M.; Martin, W. Molecular poltergeists: Mitochondrial DNA copies (numts) in sequenced nuclear genomes. PLoS Genet. 2010, 6, e1000834. [CrossRef]

49. Knoop, V. When you can't trust the DNA: RNA editing changes transcript sequences. Cell Mol. Life Sci. 2011, 68, 567-586. [CrossRef]

50. Smid, M.; Rodriguez-Gonzalez, F.G.; Sieuwerts, A.M.; Salgado, R.; Prager-Van der Smissen, W.J.; Vlugt-Daane, M.V.; van Galen, A.; Nik-Zainal, S.; Staaf, J.; Brinkman, A.B.; et al. Breast cancer genome and transcriptome integration implicates specific mutational signatures with immune cell infiltration. Nat. Commun. 2016, 7, 12910. [CrossRef]

51. Dobin, A.; Gingeras, T.R. Mapping RNA-seq reads with STAR. Curr. Protoc. Bioinformatics 2015, 51, 11.14.1-11.14.19. [CrossRef] [PubMed]

52. Liao, Y.; Smyth, G.K.; Shi, W. featureCounts: An efficient general purpose program for assigning sequence reads to genomic features. Bioinformatics 2014, 30, 923-930. [CrossRef] [PubMed]

53. Idaghdour, Y.; Hodgkinson, A. Integrated genomic analysis of mitochondrial RNA processing in human cancers. Genome Med. 2017, 9, 36. [CrossRef] [PubMed]

54. Van der Auwera, G.A.; Carneiro, M.O.; Hartl, C.; Poplin, R.; Del Angel, G.; Levy-Moonshine, A.; Jordan, T.; Shakir, K.; Roazen, D.; Thibault, J.; et al. From FastQ data to high confidence variant calls: The Genome Analysis Toolkit best practices pipeline. Curr. Protoc. Bioinformatics 2013, 43, 11.10.1-11.10.33. [CrossRef] [PubMed]

55. Thorvaldsdottir, H.; Robinson, J.T.; Mesirov, J.P. Integrative Genomics Viewer (IGV): High-performance genomics data visualization and exploration. Brief Bioinform. 2013, 14, 178-192. [CrossRef] [PubMed]

56. Robinson, J.T.; Thorvaldsdottir, H.; Winckler, W.; Guttman, M.; Lander, E.S.; Getz, G.; Mesirov, J.P. Integrative genomics viewer. Nat. Biotechnol. 2011, 29, 24-26. [CrossRef] [PubMed]

57. Lott, M.T.; Leipzig, J.N.; Derbeneva, O.; Xie, H.M.; Chalkia, D.; Sarmady, M.; Procaccio, V.; Wallace, D.C. mtDNA variation and analysis using Mitomap and Mitomaster. Curr. Protoc. Bioinformatics 2013, 44, 1.23.1-1.23.26. [CrossRef] [PubMed] 
58. Weissensteiner, H.; Pacher, D.; Kloss-Brandstatter, A.; Forer, L.; Specht, G.; Bandelt, H.J.; Kronenberg, F.; Salas, A.; Schonherr, S. HaploGrep 2: Mitochondrial haplogroup classification in the era of high-throughput sequencing. Nucleic Acids Res. 2016, 44, W58-W63. [CrossRef]

59. Gehring, J.S.; Fischer, B.; Lawrence, M.; Huber, W. SomaticSignatures: Inferring mutational signatures from single-nucleotide variants. Bioinformatics 2015, 31, 3673-3675. [CrossRef]

60. Chen, H.; Boutros, P.C. VennDiagram: A package for the generation of highly-customizable Venn and Euler diagrams in R. BMC Bioinform. 2011, 12, 35. [CrossRef]

(C) 2018 by the authors. Licensee MDPI, Basel, Switzerland. This article is an open access article distributed under the terms and conditions of the Creative Commons Attribution (CC BY) license (http:/ / creativecommons.org/licenses/by/4.0/). 